ANL- 6370

Metals, Ceramics, and Materials

(TID-4500, 16th Ed., Amended)

AEC Research and

Development Report

\author{
ARGONNE NATIONAL LABORATORY \\ 9700 South Cass Avenue \\ Argonne, Illinois
}

\title{
CORROSION STUDIES OF TERNARY ZIRCONIUM ALLOYS IN HIGH-TEMPERATURE WATER AND STEAM
}

by

R. D. Misch and C. Van Drunen

Metallurgy Division

Program 10.2 .5

Publication of this report supersedes items in the following Metallurgy Division Progress Reports:

ANL-5709, pgs. 54, 56

ANI. $5717, \mathrm{pg} \cdot 65$

ANL-6099,pgs.120-122

July 1961

Operated by The University of Chicago

under

Contract W-31-109-eng-38 


\section{DISCLAIMER}

This report was prepared as an account of work sponsored by an agency of the United States Government. Neither the United States Government nor any agency Thereof, nor any of their employees, makes any warranty, express or implied, or assumes any legal liability or responsibility for the accuracy, completeness, or usefulness of any information, apparatus, product, or process disclosed, or represents that its use would not infringe privately owned rights. Reference herein to any specific commercial product, process, or service by trade name, trademark, manufacturer, or otherwise does not necessarily constitute or imply its endorsement, recommendation, or favoring by the United States Government or any agency thereof. The views and opinions of authors expressed herein do not necessarily state or reflect those of the United States Government or any agency thereof. 


\section{DISCLAIMER}

Portions of this document may be illegible in electronic image products. Images are produced from the best available original document. 


\section{TABLE OF CONTENTS}

$\underline{\text { Page }}$

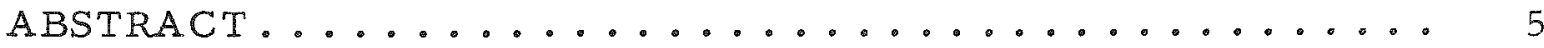

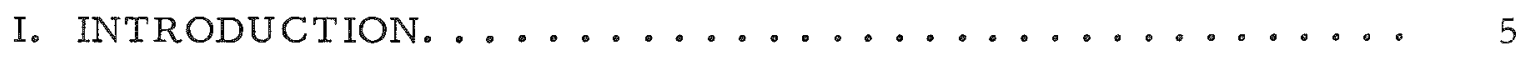

II. EXPERIMENTAL_...................... 8

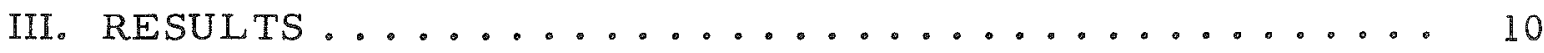

A. Alloys made with $\mathrm{Sc}_{2} \mathrm{O}_{3}$ and $\mathrm{Y}_{2} \mathrm{O}_{3} \ldots \ldots \ldots \ldots \ldots \ldots \ldots$

B. Alloys made with scandium and yttrium metal ....... 19

C. Microstructure of a Sc Mo alloy ................. 21

D. Examination of stripped corrosion films .......... 23

IV. DISCUSSION ......................... 32

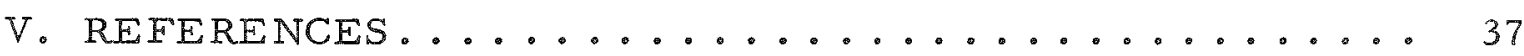




\section{LIST OF FIGURES}

No.

Title

Page

1 Specimens of $0.025 \mathrm{w} / \mathrm{o}$ Sc, $0.053 \mathrm{w} / \mathrm{O}$ Mo zirconium alloy after exposure to steam at $540^{\circ} \mathrm{C}, 600 \mathrm{psi} \ldots . . .$.

2 Weight gains in $\mathrm{mg} / \mathrm{dm}^{2}$ for three specimens of the alloy $0.025 \mathrm{w} / \mathrm{OSc}, 0.053 \mathrm{w} / \mathrm{O}$ Mo corroded in steam at $540^{\circ} \mathrm{C}, 600 \mathrm{psi} \ldots \ldots \ldots \ldots \ldots . \ldots \ldots$

$3 \quad$ Log-log plot of the data for Specimen B in Figure 2....

4 Cold-rolled, $0.025 \mathrm{w} / \mathrm{O} \mathrm{Sc}-0.053 \mathrm{w} / \mathrm{o}$ Mo alloy showing the interface between metal and oxide after corrosion

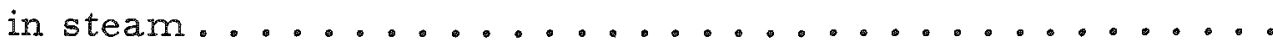

5 Interior of Specimen shown in Figure $4 \ldots \ldots$

6 Annealed and quenched $0.025 \mathrm{w} / \mathrm{OSc}-0.053 \mathrm{w} / \mathrm{O}$ Mo alloy showing the interface between oxide and metal

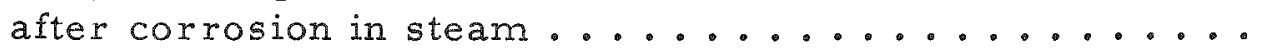

7 Annealed and quenched $0.025 \mathrm{w} / \mathrm{OSc}-0.053 \mathrm{w} / \mathrm{O} \mathrm{Mo}$ alloy showing the interface between oxide and metal

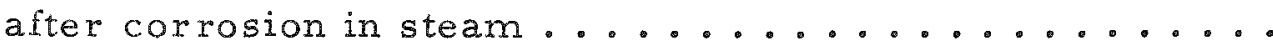

8 Interior of specimen shown in Figures 6 and $7 \ldots \ldots$

9 Oxide film from zirconium crystal bar exposed to

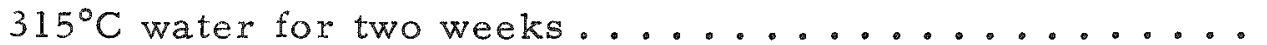

10 Oxide film from an alloy containing $0.16 \mathrm{w} / 0 \mathrm{Sc}$ and $0.34 \mathrm{w} / \mathrm{o}$ Mo, corroded in steam $\left(540^{\circ} \mathrm{C}, 150 \mathrm{psi}\right)$ for $212 \mathrm{hr} \ldots \ldots \ldots \ldots \ldots \ldots \ldots \ldots . \ldots \ldots \ldots$ 
I. Results of Corrosion Testing Zirconium Alloys

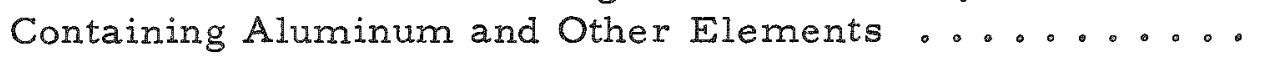

II. Results of Corrosion Testing Zirconium Alloys

Containing Scandium, Yttrium, and Other Elements .....

III. Results of Corrosion Testing of Scandium Alloys

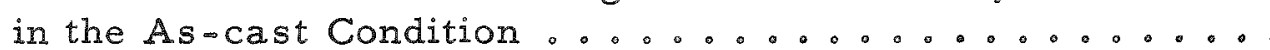

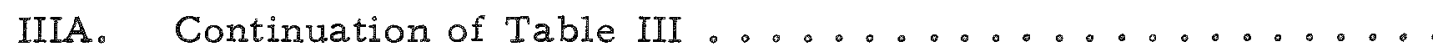

IV. Results of Corrosion Testing of Yttrium Alloys

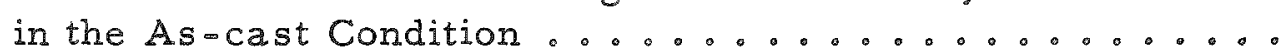

V. Results of Corrosion Testing after Vacuum Annealing at $1000^{\circ} \mathrm{C}$ for $15 \mathrm{~min}$ (sealed in quartz) and Water

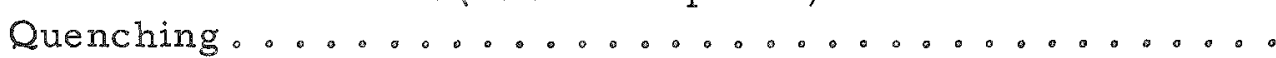

VI. Results of Corrosion Testing after Vacuum Annealing

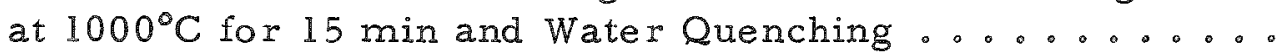

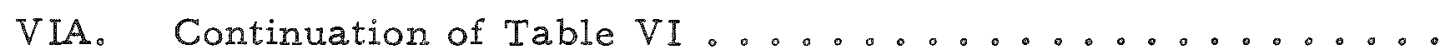

VII. Results of Corrosion Testing of As-cast $\mathrm{Y}, \mathrm{Nb}$, and

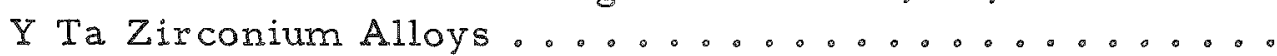

VIII. Results of Corrosion Testing of Zirconium Alloys Containing $\mathrm{Yb}$ and $\mathrm{Nb} \ldots \ldots \ldots \ldots$

IX. Spectroscopic Analysis of Ternary Alloys Containing 0.05 atomic per cent $A, 0.05$ atomic per cent $B \ldots 20$

X. Results of Corrosion Testing of Selected Zirconium Alloys in Steam $\left(540^{\circ} \mathrm{C}, 600 \mathrm{psi}\right) \ldots \ldots \ldots$

XI. Hydrogen Analyses of Zirconium Specimens before and after Corrosion in Steam $\left(540^{\circ} \mathrm{C}, 600 \mathrm{psi}\right) \ldots \ldots$

XII. Molar Volumes of $\mathrm{MO}_{2}$ Compounds .............. 33

XIII. Relative Cation Field Strengths and Compound Formation

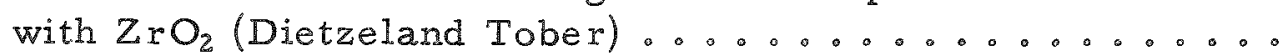


CORROSION STUDIES OF TERNARY ZIRCONIUM ALLOYS IN HIGH-TEMPERATURE WATER AND STEAM

by

R. D. Misch and C. Van Drunen

\begin{abstract}
The alloying of zirconium to improve corrosion resistance has an empirical basis, and satisfactory explanations for the alloying effects are not available. A theory of compensating valencies in the corrosion oxide is proposed, in which cations of lower and higher valence than zirconium $(+4)$ are present in ratios such that electrostatic neutrality is ensured. An example is an alloy containing equimolar amounts of scandium $(+3)$ and niobium $(+5)$.

A number of zirconium alloys were prepared in which scandium or yttrium were paired with elements capable of $a+5$ or +6 valence. The ternary alloys containing scandium were superior to the alloys containing yttrium. The alloys containing scandium plus molybdenum, tantalum, or tungsten had relatively long lifetimes in steam at $540^{\circ} \mathrm{C}$ and $600 \mathrm{psi}$ as compared with other alloy combinations, including Zircaloy -2 . A quenched alloy containing $0.025 \mathrm{w} / \mathrm{O} \mathrm{Sc}$ and $0.053 \mathrm{a} / \mathrm{o} \mathrm{Mo}$ (that is, $0.05 \mathrm{~mol} \%$ of each additive) corroded approximately according to a cubic law up to $758 \mathrm{hr}$, at which point the rate suddenly increased in a manner suggest ing hydrogen damage.

Examination of the oxide film from alloys containing scandium and molybdenum showed only monoclinic $\mathrm{ZrO}_{2}$. It is believed that stabilization of this form of $\mathrm{ZrO}_{2}$ instead of the cubic or tetragonal forms is a factor in promoting corrosion resistance. In this way the protective character of the film can be improved independently of the addition of cathodes.
\end{abstract}

\title{
I. INTRODUCTION
}

The development of zirconium alloys for use in water at high temperature has concentrated on alloys containing various combinations of tin, iron, nickel, and chromium. Extensive screening of zirconium binary alloys has shown that most other elements are deleterious to the corrosion resistance of zirconium.(1) 
In terms of understanding these effects, the role of iron and nickel is best understood on the basis of the theory of hydrogen damage to the protective oxide film. (2) Tin does not fit this picture because this metal has a relatively high hydrogen overvoltage. However, tin is able to counteract the effect of nitrogen in promoting corrosion. Phosphorus can also do this to a lesser extent.(3) Thomas has suggested that tin ions associate with nitrogen ions in the $\mathrm{ZrO}_{2}$ lattice to reduce the mobility of oxygen anions. (4)

A valuable contribution to understanding the role of substitutional ions in a corrosion scale has been made by Hauffe, who formulated rules for selecting additives based on the two cases of predominant ionic or electronic conductivity.(5) The equilibria which form the basis of the Hauffe rules require that suppression of ionic conductivity will promote electronic conductivity and vice versa. This method is characterized by the name "valency control." The Hauffe rules have not been useful in the case of zirconium, and the reasons for this are not understood. One possibility is that conduction in $\mathrm{ZrO}_{2}$ is "mixed, "and, therefore, both types of conduction must be suppressed.

Very little is known about the effect of two or more elements on the $\mathrm{ZrO}_{2}$ corrosion scale except for the apparent compensating effect of nitrogen and tin mentioned above. That interactions can take place within the oxide is clear from the observation of Johnson(6) that $\mathrm{ZrO}_{2}$ formed a cubic modification in the presence of $3 \mathrm{w} / 0 \mathrm{Y}_{2} \mathrm{O}_{3}$ or $3 \mathrm{w} / 0 \mathrm{Nb}_{2} \mathrm{O}_{5}$. In a ternary composition containing $2 \mathrm{w} / 0 \mathrm{Y}_{2} \mathrm{O}_{3}$ and $2 \mathrm{w} / \mathrm{o} \mathrm{Nb}_{2} \mathrm{O}_{5}$ the cubic structure did not appear.

The changes to be expected in the $\mathrm{ZrO}_{2}$ lattice upon the substitution of higher or lower valent foreign cations will depend upon the type of defects which $\mathrm{ZrO}_{2}$ can form most readily. Available evidence favors an anion-defect structure: therefore adjustments in lattice equilibria will involve changes in the number of oxygen vacancies.

When cations with charge less than four are substituted for zirconium ions, the number of oxygen ion vacancies will increase to maintain electrical neutrality. The foreign cations will have a net negative charge relative to the lattice, while the oxygen vacancies will have a net positive charge。

When cations with charges greater than four are substituted for zirconium ions, the number of oxygen ion vacancies will decrease to a minimum. After this point, the further introduction of higher valent cations requires the presence of electrons in the lattice. Consequently. the $\mathrm{ZrO}_{2}$ will become a better n-conductor.

If the aliovalent additives are present in such a proportion that their average charge is +4 , then compensating changes in the defect 
equilibria will not be required. However, the presence of such compensated additives may have other effects which can influence the corrosion process. Changes may take place in the oxide structure, diffusion rates, and electrical conductivity. The diffusion rate of oxygen anions may be influenced by the charges on the lower and higher valent foreign cations.

Depending on the ionization potentials of the foreign cations, the conductivity of the oxide is likely to be increased. The lower valent cations $\mathrm{Sc}^{3+}$ and $\mathrm{Y}^{3+}$ are not likely to participate in electron exchange because of their noble gas structure, but exchange may occur with nonnoble gas ions such as $\mathrm{Fe}^{3+}$. Combinations of this type, e.g., $\mathrm{Fe}^{3+}$ and $\mathrm{Ta}^{5+}$, are worthy of consideration but did not come within the scope of this study.

In summary, the procedure of adding two or more elements to zirconium with the object of influencing the corrosion rate has a number of potential advantages. These include:

1) The activation energy of diffusion may be higher if the $\mathrm{ZrO}_{2}$ lattice contains dissolved cations of differing valence, size, and electronic configurations.

2) It may be possible to stabilize a favorable $\mathrm{ZrO}_{2}$ structure with minimum change in the number of point defects. Stabilization of the monoclinic form is believed to promote maximum resistance to corrosion. The reasons for this are discussed later.

3) The $\mathrm{ZrO}_{2}$ lattice may be strengthened by the incorporation of ions having different types of bonding characteristics. Two (or more) additives may act synergistically to minimize stresses and enhance solubility in the $\mathrm{ZrO}_{2}$. 


\section{EXPERIMENTAL}

Based on these considerations, an investigation was begun on the effect of the simultaneous addition of lower and higher valence elements on the corrosion resistance of zirconium. These elements were chosen to avoid the formation of cathodes which might promote corrosion resistance by a different mechanism. Therefore, elements such as iron, nickel, copper, palladium, platinum, etc., were excluded with one exception.

The choice of alloying additives was governed by valence, and melting point or boiling point. The most suitable lower valent additives appeared to be Al, Sc, Y, and $\mathrm{Yb}^{*}$ (in order of atomic number), whereas the high valent additives were V, Cr, Mn, As, Nb, Mo, Sb, Ta, W, Pd, and Bi. These elements are capable of forming +5 or +6 cations. In several cases, nickel, tin, and thorium were added. Ionic size and oxide structures were not considered in making this selection.

The lower and higher valent elements were added in atomic ratios of 1 to 1,1 to 2 , or 1 to 3 . Larger amounts of the higher valent element were used on the basis that the higher valence might not be fully realized in solution in the $\mathrm{ZrO}_{2}$ lattice. The total alloying content did not exceed 1 weight per cent.

The alloys were prepared by arc-melting buttons from sections of reactor-grade zirconium crystal bar which was corrosion resistant after 1 week in water at $350^{\circ} \mathrm{C}$. Initially, a $\frac{1}{8}$-in. diameter hole was drilled into each piece of crystal bar and the additives were placed inside. A plug of zirconium rod was then inserted and anchored by hammering the edge of the hole. During the course of the investigation these precautions were found to be unnecessary, and subsequently additives were simply placed under the zirconium. The metals used were in the form of powder or turnings or were cut from sheet. A comparison of specimen weights before and after melting showed that weight changes were very small. The appearance of the water-cooled copper mold was also an indication of possible loss of material from the melt. None of the alloys discussed below gave the appearance of losing the additives during melting.

The additives were reagent grade or were claimed to have purities of $99 \%$ or better. In the course of the investigation, the "scandium" and "yttrium"powders initially used were found to be sesquioxides instead of metals. This raised a doubt as to whether these oxides were reduced and alloyed with zirconium or whether they remained as undissolved second phase.

* Ytterbium metal in the form of a button casting was kindly provided by Dr. H. A. Wilhelm of Ames Laboratory. Ames, Iowa. 
According to the free energies of formation of $\mathrm{ZrO}_{2}$ and $\mathrm{Y}_{2} \mathrm{O}_{3}$, the latter oxide will be reduced by zirconium at its melting point of $1850^{\circ} \mathrm{C}$. Several yttrium-zirconium alloys prepared with $\mathrm{Y}_{2} \mathrm{O}_{3}$ were analyzed chemically and examined metallographically. The yttrium was present in the nominal amounts and the metallographic structure was consistent with an alloy. Therefore, the use of oxide did not vitiate the results. Data on the free energy of formation of $\mathrm{Sc}_{2} \mathrm{O}_{3}$ could not be found, but reduction and alloying seem likely in this case also.

Comparable corrosion results were obtained from later zirconium alloys using metallic scandium and yttrium. Therefore, the use of oxide for these additives did not detract from the conclusions of the screening procedure.

Each alloy was arc-melted three times. The buttons were turned over prior to the second and third meltings. They were then tested as cast or after treating in various ways. Details of subsequent treatment are presented with the data for simplicity.

Corrosion testing was carried out in degassed, distilled water at $350^{\circ} \mathrm{C}$ or in steam at $540^{\circ} \mathrm{C}$ and $600 \mathrm{psi}$. In some cases, water testing was followed by steam exposure without cleaning the specimens when the corrosion rate in water was low. 


\section{RESULTS}

Observations of corrosion resistance are presented in a series of tables. For the initial purposes of this survey the alloys were judged only on the basis of appearance. A quantitative comparison did not appear justified at the beginning of a survey of this type, and consequently specific weight gains were not determined. All alloys were kept in test as long as their appearance indicated moderately good corrosion resistance. A specimen was removed from test when the surface was covered with white oxide, or when the oxide was obriously thickening or beginning to break away from the surface. In several cases the tests were discontinued although the appearance justified continuance of the corrosion exposure. These times are indicated by an asterisk. Remoral of a specimen because of failing corrosion resistance is indicated by an $\mathrm{x}$.

The first specimens (Tables I, II, III) were cut into halves after arc melting. One-half was left in the as-cast condition and the other half was heated in a stainless steel vacuum tube furnace to $1000^{\circ} \mathrm{C}$ for one hour. The specimens were then quenched into Wood's metal (approximately $100^{\circ} \mathrm{C}$ ) while still under vacuum.

Table I shows four combinations based on aluminum. All had high corrosion rates indicating that $\mathrm{V}, \mathrm{Nb}, \mathrm{Ta}$, or $\mathrm{W}$ are not able to compensate for the deleterious effect of aluminum. No additional alloys with aluminum were made.

Table I

RESULTS OF CORROSION TESTING ZIRCONIUM ALLOYS CONTAINING ALUMINUM AND OTHER ELEMENTS

(Total Content of Alloying Constituents 1 wo)

\begin{tabular}{|c|c|c|c|c|c|}
\hline \multirow{2}{*}{$\begin{array}{l}\text { Composition } \\
\text { In Atonic } \\
\text { Per Cent }\end{array}$} & \multirow[t]{2}{*}{ Treatment } & \multicolumn{4}{|c|}{$\begin{array}{l}\text { Appearance after Test } \\
\text { Hours in Water at } 350^{\circ} \mathrm{C}\end{array}$} \\
\hline & & 1 & 17 & 185 & 684 \\
\hline $1.2 \% \mathrm{Al}\}$ & as cast & white, flaking $x$ & & & \\
\hline $1.2 \% \vee J$ & quenched & & white, flakingx & & \\
\hline $0.76 \% \mathrm{Al}$ & as cast & & white, flaking $X$ & & \\
\hline $0.76 \% \mathrm{Nb}$ & quenched & & white, flakingx & & \\
\hline $0.43 \% \mathrm{Al}$ & as cast & & & White, some flaking $x$ & \\
\hline $0.43 \% \mathrm{Ta}$ & quenched & & & white, some flaking $x$ & \\
\hline $0.43 \% \mathrm{Al}$ & as cast & & turning whitex & & \\
\hline $0.43 \% \mathrm{~W}$ & quenched & & furning whitex & & \\
\hline Zr control & as cast & & & & iridescent black* \\
\hline
\end{tabular}

: Discontinued although appearance justified continuance.

$\mathrm{X}$ Indicates either that the appearance of the specimens warranted rejection at the time shown or that testing was stopped. 
A. Alloys Made with $\mathrm{Sc}_{2} \mathrm{O}_{3}$ and $\mathrm{Y}_{2} \mathrm{O}_{3}$

A number of combinations of scandium and yttrum with other additives were prepared next. The results are presented in Table II. It w 11 be noted that the mol ratios of the lower and higher valent elements do not cor respond exactly to the indicated proportions. This is so because the percentages were recalculated to correct for the use of oxide.

Table II

RESULTS OF CORROSION TESTING ZIRCONIUM ALLOTS CONAINIAG SCANDIUM YTTRIUM ANO OTHER FLEMENTS

(Jotal Content of Alloying Constituents I wol

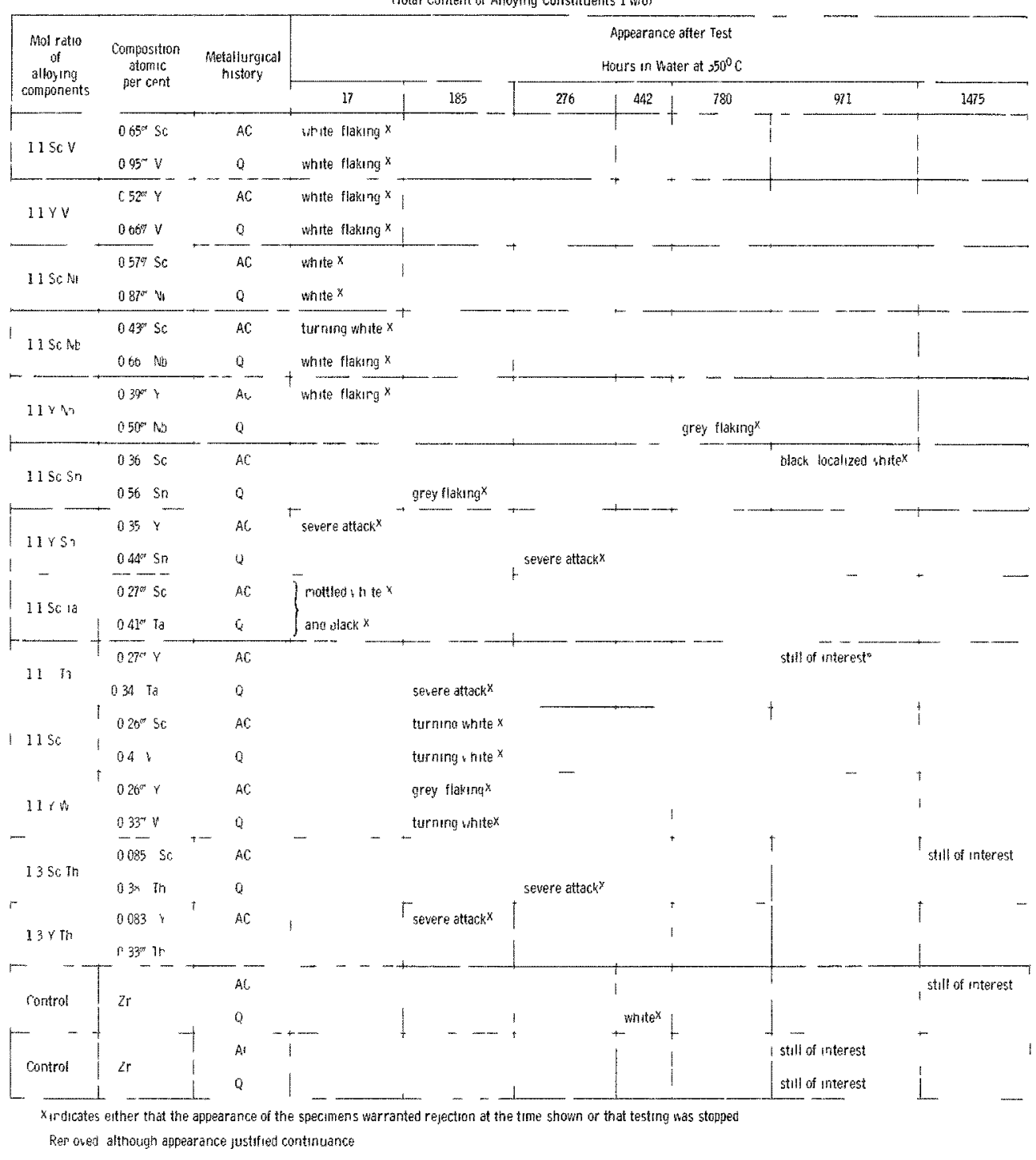

The following conclusions were drawn from the data of Table II.

First, some gaseous pickup probably occurred during annealing (in the stainless steel tube furnace) because the quenched controls were less corrosion resistant. However, some of the alloys were more resistant in the quenched condition, and it was concluded that contamination could be more than offset by favorable alloying and heat treatment. In general, the appearances of the corrosion films on the quenched specimens were more uniform. 
It was apparent that scandium and yttrium were usually deleterious to corrosion resistance. Although not shown in the table, zirconium alloys containing $2 \mathrm{a} / \mathrm{O} \mathrm{Sc}$ and $2 \mathrm{a} / \mathrm{O} \mathrm{Y}$ had poor corrosion resistance in $350^{\circ} \mathrm{C}$ water, developing a white, flaking layer after $16 \mathrm{hr}$. The effect of scandium was not compensated by the addition of nickel, which can form cathodes to prevent hydrogen damage. Niobium had a favorable influence when yttrium was present but not when scandium was present. The opposite effect was noted with tin, which was able to compensate for scandium but not for yttrium. Another contrast was noted with thorium, which was considered to be a deleterious additive. Scandium and thorium seemed to compensate, but yttrium and thorium did not. This alloy was prepared in a 1 to 3 ratio by miscalculation, and this ratio was maintained in later work. Tantalum seemed to be able to compensate for yttrium to a slight extent.

The number of combinations based on scandium and yttrium was expanded further to take in a greater number of elements which could have valences of +5 or greater. Corrosion data for these scandium alloys in the as cast condition are presented in Tables III and IIIA. The scandiummolybdenum alloys were also tested in the annealed condition as shown in the table. Each specimen was tested for a maximum of $80 \mathrm{hr}$ in $350^{\circ} \mathrm{C}$ water. Nine specimens were rejected at the end of this time. The remainder were transferred to steam at $540^{\circ} \mathrm{C}$ and $600 \mathrm{psi}$ without cleaning. Most of the specimens were eliminated after $229 \mathrm{hr}$ in steam, with the exception of ScMo, ScTa, and ScW.

The results of corrosion testing as-cast alloys containing yttrium with $\mathrm{Cr}, \mathrm{Mn}, \mathrm{As}, \mathrm{Nb}, \mathrm{Mo}, \mathrm{Sb}, \mathrm{Ta}, \mathrm{W}, \mathrm{Pb}, \mathrm{Bi}$ and $\mathrm{Th}$ are shown in Table IV. The yttrium-molybdenum alloys were also tested in the annealed condition, as shown in the table. Certain similarities with the scandium combinations are obvious. The manganese combinations were very poor, whereas YTa showed some promise.

After conclusion of the above tests, those specimens which had not corroded too badly were cleaned by vapor-blasting and etching, and were then degassed at $1100^{\circ} \mathrm{C}$ for $1 \mathrm{hr}$ in a vacuum induction furnace. They were then sealed in evacuated quartz capsules, heated to $1000^{\circ} \mathrm{C}$ for $15 \mathrm{~min}$, and water quenched. Only a selection of specimens was given this treatment because the most corrosion-resistant compositions were still in test: the least corrosion-resistant compositions were not considered worthy of further attention. The data are given in Table V, Table VI, and Table VIA. The data of Tables $V$ and VI did not change the corrosion picture of the as-cast alloys. The alloys which had superior corrosion resistance in both the as-cast and quenched conditions were the ternaries containing ScMo. ScTa, and ScW. The combinations of yttrium with Mo, Ta and $W$ were inferior although better than most of the other combinations. 
Table III

RESULTS OF CORROSION TESTING OF SCANDIUM ALLOYS IN THE AS-CAST CONDITION

\begin{tabular}{|c|c|c|c|c|c|c|c|c|c|c|c|}
\hline \multirow{3}{*}{$\begin{array}{l}\text { Nominal } \\
\text { Composition, } \\
\text { Atomic } \\
\text { Per Cent }\end{array}$} & \multicolumn{11}{|c|}{ Appearance after Test } \\
\hline & \multicolumn{2}{|c|}{ Hours in Water at $350^{\circ} \mathrm{C}$} & \multicolumn{9}{|c|}{ Additional Hours in Steam $1540^{\circ} \mathrm{C}$ and $600 \mathrm{psil}$} \\
\hline & 16 & 80 & 67 & 229 & 326 & 446 & 694 & 928 & 1136 & 1344 & 1794 \\
\hline $0.30 \mathrm{Sc} 0.44 \mathrm{Cr}$ & chalky whitex & & & & & & & & & & \\
\hline $0.20 \mathrm{sc} 0.62 \mathrm{Cr}$ & $\begin{array}{l}\text { grey and } \\
\text { white patches } x\end{array}$ & & & & & & & & & & \\
\hline $0.14 \mathrm{Sc} 0.66 \mathrm{Cr}$ & $\begin{array}{l}\text { dark grey with } \\
\text { interference } \\
\text { colors }\end{array}$ & $\begin{array}{l}\text { grey and whitel } \\
\text { patches }\end{array}$ & & & & & & & & & \\
\hline 0.29 Sc $0.45 \mathrm{mn}$ & grey and white & e white flakrng ${ }^{X}$ & & & & & & & & & \\
\hline 0.19 Sc $0.58 \mathrm{Mn}$ & grey and white & e white flaking ${ }^{x}$ & & & । & & & 1 & & & \\
\hline $0.14 \mathrm{Sc} 0.66 \mathrm{Mn}$ & grey and white & ' white flaking ${ }^{x}$ & & & & & & & & & \\
\hline $0.25 \mathrm{Sc} 0.39 \mathrm{As}$ & $\begin{array}{l}\text { black, over- } \\
\text { lying white }\end{array}$ & $1^{\text {all whitex }}$ & 1 & & 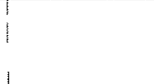 & & & & & & \\
\hline 0.14 Sc 0.44 As & $\begin{array}{l}\text { dark brown, } \\
\text { white specks }\end{array}$ & 'all whitex & & & I & & & & 1 & & \\
\hline 0.11 Sc 0.51 As & $\begin{array}{l}\text { dark brown, } \\
\text { white specks }\end{array}$ & $\begin{array}{l}\text { dark brown } \\
\text { and grey }\end{array}$ & $\begin{array}{l}\text { lighe grey } \\
\text { plus oxide } \\
\text { mounds }\end{array}$ & chalky coat ${ }^{x}$ & 1 & & & & & & \\
\hline $0.21 \mathrm{Sc} 0.32 \mathrm{Nb}$ & $\begin{array}{l}\text { grey and white } \\
\text { patches }\end{array}$ & e & & 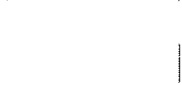 & & & I & i & & & \\
\hline $0.13 \mathrm{sc} 0.40 \mathrm{Nb}$ & $\begin{array}{l}\text { inferference } \\
\text { colors }\end{array}$ & $\begin{array}{l}\text { 'black, small } \\
\text { white patches }\end{array}$ & $\begin{array}{l}\text { grey, } \\
\text { light grey } \\
\text { moundsx }\end{array}$ & & & & & $i$ & $i$ & & \\
\hline $0.09 \mathrm{Sc} 0.42 \mathrm{Nb}$ & $\begin{array}{l}\text { interference } \\
\text { colors }\end{array}$ & $\begin{array}{l}\text { dark grey, } \\
\text { |white specks }\end{array}$ & $\begin{array}{l}\text { grey, } \\
\text { light grey } \\
\text { mounds } x\end{array}$ & $\ldots$ & & & ! & 1 & & & \\
\hline $0.22 \mathrm{Sc} 0.33 \mathrm{Mo}$ & $\begin{array}{l}\text { interference } \\
\text { colors, white } \\
\text { specks }\end{array}$ & $\begin{array}{l}\text { dark, white } \\
\text { specks }\end{array}$ & $\begin{array}{l}\text { dark and } \\
\text { light grey }\end{array}$ & $\begin{array}{l}\text { light grey with } \\
\text { oxide mounds }\end{array}$ & & & & & i & & \\
\hline $0.13 \mathrm{Sc} 0.40 \mathrm{Mo}$ & $\begin{array}{l}\text { interference } \\
\text { colors, white } \\
\text { specks }\end{array}$ & $\begin{array}{l}\text { dark, white } \\
\text { specks }\end{array}$ & $\begin{array}{l}\text { dark and } \\
\text { light grey }\end{array}$ & Iight grey" & t & & & 1 & 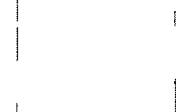 & & \\
\hline $0.09 \mathrm{Sc} 0.42 \mathrm{Mo}$ & $\begin{array}{l}\text { interference } \\
\text { colors, white } \\
\text { specks }\end{array}$ & $\begin{array}{l}\text { I dark, white } \\
\text { specks }\end{array}$ & $\begin{array}{l}\text { dark and } \\
\text { light grey }\end{array}$ & $\begin{array}{l}\text { medium grey, } \\
\text { I bad spot }\end{array}$ & & & & & & & \\
\hline (vacuum anneal & d $1 \mathrm{hr}$ at $11000^{\circ} \mathrm{C}$ & $C$ and furnace coo & oledy & & & & & & & & \\
\hline $0.22 \mathrm{Sc} 0.33 \mathrm{Mo}$ & I not tesied & not tested & grey & not examined & $\begin{array}{l}\text { grey, white } \\
\text { on edges }\end{array}$ & $\begin{array}{l}\text { translucent } \\
\text { grey }\end{array}$ & $\begin{array}{l}\text { unchanged } \\
\text { plus several } \\
\text { bad spots }\end{array}$ & | unchanged & unchanged & unchanged & slow \\
\hline $0.13 \mathrm{Sc} 0.40 \mathrm{Mo}$ & not tested & not tested & $\begin{array}{l}\text { grey with } \\
\text { white specks }\end{array}$ & not examined & $\begin{array}{l}\text { grey with } \\
\text { white specks }\end{array}$ & $\begin{array}{l}\text { translucent } \\
\text { grey }\end{array}$ & $\begin{array}{l}\text { unchanged } \\
\text { plus several } \\
\text { bad spots }\end{array}$ & , unchanged & unchanged & unchanged & $\begin{array}{l}\text { growth } \\
\text { of } \\
\text { bad } \\
\text { snots }\end{array}$ \\
\hline $0.09 \mathrm{Sc} 0.42 \mathrm{Mo}$ & not tested & ; not tested & $\begin{array}{l}\text { grey with } \\
\text { white specks }\end{array}$ & not examined & $\begin{array}{l}\text { grey with } \\
\text { white specks }\end{array}$ & $\begin{array}{l}\text { translucent } \\
\text { dark grey }\end{array}$ & unchanged & unchanged & $\begin{array}{l}\text { unchanged } \\
\text { plus several } \\
\text { bad spots }\end{array}$ & unchanged & \\
\hline $0.18 \mathrm{Sc} 0.27 \mathrm{Sb}$ & $\begin{array}{l}\text { interference } \\
\text { colors }\end{array}$ & dark grey & $\begin{array}{l}\text { dark and } \\
\text { light grey }\end{array}$ & light greyx & & & & 1 & & & \\
\hline $0.10 \mathrm{Sc} 0.32 \mathrm{Sb}$ & $\begin{array}{l}\text { interference } \\
\text { colors }\end{array}$ & $\begin{array}{l}\text { dark, come } \\
\text { light grey }\end{array}$ & $\begin{array}{l}\text { dark grey, } \\
\text { oxide mounds }\end{array}$ & $\begin{array}{l}\text { accelerating } \\
\text { attack }\end{array}$ & & : & & & 1 & & \\
\hline $0.075 \mathrm{sc} 0.35 \mathrm{Sb}$ & $\begin{array}{l}\text { interference } \\
\text { colors }\end{array}$ & $\begin{array}{l}\text { dark, some } \\
\text { light grey }\end{array}$ & $\begin{array}{l}\text { 'dalk grey, } \\
\text { oxide mounds }\end{array}$ & $\begin{array}{l}\text { accelerating } \\
\text { attack }\end{array}$ & & & & 1 & & & \\
\hline $0.135 \mathrm{Sc} 0.20 \mathrm{Ta}$ & $\begin{array}{l}\text { interference } \\
\text { colors }\end{array}$ & $\begin{array}{l}\text { dark grey, } \\
\text { white specks }\end{array}$ & $\begin{array}{l}\text { grey, white } \\
\text { patches } \\
\text { and mounds } x\end{array}$ & & & $i$ & & 1 & 1 & & \\
\hline $0.075 \mathrm{Sc} 0.23 \mathrm{Ta}$ & interference & interference & grey, white & & & ' & & 1 & & & \\
\hline & colors & $\begin{array}{l}\text { colors and } \\
\text { specks }\end{array}$ & patches $x$ & & & $i$ & & 1 & & 1 & \\
\hline $0.05 \mathrm{Sc} 0.23 \mathrm{Ta}$ & $\begin{array}{l}\text { Interference } \\
\text { colors }\end{array}$ & dark grey & $\begin{array}{l}\text { dark grey, } \\
\text { white specks }\end{array}$ & $\begin{array}{l}\text { Ilght grey, } \\
\text { edge cracking }\end{array}$ & unchanged & $\begin{array}{l}\text { IIght grey } \\
\text { and brown, } \\
\text { edge cracking }\end{array}$ & unchanged & $\begin{array}{l}\text { 'light grey, } \\
\text { edge cracking }\end{array}$ & $\begin{array}{l}\text { similar plus } \\
\text { white patches }\end{array}$ & \begin{tabular}{l|l} 
thick grey \\
$s\left|\begin{array}{l}\text { layer, edge } \\
\text { attack }\end{array}\right|$
\end{tabular} & $\begin{array}{l}\text { thick grey } \\
\text { layer, edge } \\
\text { attack }\end{array}$ \\
\hline & 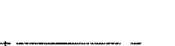 & 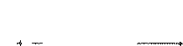 & $\ldots$ & $\ldots$ & $\ldots$ & 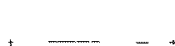 & $\ldots$ & $\ldots$ & 1 & & | See Table IIA \\
\hline $0.13 \operatorname{sc} 0.20 \mathrm{~W}$ & $\begin{array}{l}\text { grey, inter- } \\
\text { ference colors }\end{array}$ & $\begin{array}{l}\text { dark grey } \\
\text { whth white } \\
\text { specks }\end{array}$ & $\begin{array}{l}\text { grey, white } \\
\text { specks }\end{array}$ & $\begin{array}{l}\text { Inght grey, } \\
\text { white patch }\end{array}$ & unchanged & $\begin{array}{l}\text { simular plus } \\
\text { edige cracking }\end{array}$ & ' unchanged & I unchanged & unchanged & unchanged & $\begin{array}{l}\text { thick grey } \\
\text { layer edge } \\
\text { attack }\end{array}$ \\
\hline $0.07 \mathrm{Sc} 0.22 \mathrm{~W}$ & $\begin{array}{l}\text { interference } \\
\text { colors }\end{array}$ & dark grey & $\begin{array}{l}\text { grey, white } \\
\text { specks }\end{array}$ & $\begin{array}{l}\text { Ilght grey, } \\
\text { edge cracking }\end{array}$ & unchanged & unchanged & unchanged & unchanged & unchanged & unchanged & \begin{tabular}{|l} 
thick grey \\
layer edge \\
attack
\end{tabular} \\
\hline 0.05 Sc $0.23 w$ & $\begin{array}{l}\text { interference } \\
\text { colors }\end{array}$ & $\begin{array}{l}\text { I dark grey } \\
\text { with white } \\
\text { specks }\end{array}$ & $\begin{array}{l}\text { grey, white } \\
\text { specks }\end{array}$ & $\begin{array}{l}\text { light grey, } \\
\text { white patch }\end{array}$ & unchanged & $\begin{array}{l}\text { similar plus } \\
\text { edge sracking } \\
\text { | }\end{array}$ & unchanged & unchanged & unchanged & unchanged & $\begin{array}{l}\text { thick grey } \\
\text { layer edge } \\
\text { attack } \\
\text { See Table IIIA }\end{array}$ \\
\hline $0.12 \mathrm{sc} 0.18 \mathrm{~Pb}$ & $\begin{array}{l}\text { Interference } \\
\text { colors }\end{array}$ & $\begin{array}{l}\text { dark and } \\
\text { light grey }\end{array}$ & $\begin{array}{l}\text { dark grey, } \\
\text { 'oxide mounds }\end{array}$ & $\begin{array}{l}\text { accelerating } \\
\text { attack }\end{array}$ & & | & & † - & 1 & & See lable ШA \\
\hline $0.065 \mathrm{Sc} 0.20 \mathrm{~Pb}$ & $\begin{array}{l}\text { interference } \\
\text { colors, some } \\
\text { grey oxide }\end{array}$ & $\begin{array}{l}\text { dark and } \\
\text { light grey }\end{array}$ & $\begin{array}{l}\text { white, with } \\
\text { oxide mounds }\end{array}$ & $\begin{array}{l}\text { oxide layer- } \\
\text { ing and } \\
\text { flaking }\end{array}$ & $i$ & & 1 & 1 & ! & & \\
\hline $0.05 \mathrm{Sc} 0.21 \mathrm{~Pb}$ & $\begin{array}{l}\text { interference } \\
\text { colors, some } \\
\text { grey oxide }\end{array}$ & $\begin{array}{l}\text { dark brown, } \\
\text { grey }\end{array}$ & $\begin{array}{l}\text { whice, with } \\
\text { oxide mounds }\end{array}$ & $\begin{array}{l}\text { almost } \\
\text { disintegrated } X\end{array}$ & & & 1 & & 1 & & \\
\hline $0.12 \operatorname{Sc} 0.18 \mathrm{Bi}$ & $\begin{array}{l}\text { interference } \\
\text { colors, some } \\
\text { grey oxide }\end{array}$ & $\begin{array}{l}\text { interference } \\
\text { colors, some } \\
\text { grey }\end{array}$ & $\begin{array}{l}\text { dark and } \\
\text { light grey }\end{array}$ & $\begin{array}{l}\text { dark and }{ }^{x} \\
\text { light grey }\end{array}$ & & & & & 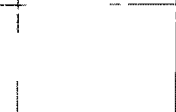 & & \\
\hline $0.065 \mathrm{Sc} 0.20 \mathrm{Br}$ & $\begin{array}{l}\text { interference } \\
\text { colors, some } \\
\text { grey oxide }\end{array}$ & $\begin{array}{l}\text { interference } \\
\text { colors, some } \\
\text { grey }\end{array}$ & $\begin{array}{l}\text { light grey } \\
\text { with oxide } \\
\text { mounds }\end{array}$ & $\begin{array}{l}\text { accelerating } \\
\text { attack }\end{array}$ & | & & 1 & & & & \\
\hline $0.04 \mathrm{Sc} 0.20 \mathrm{Bi}$ & $\begin{array}{l}\text { interference } \\
\text { colors, some } \\
\text { grey oxide }\end{array}$ & $\begin{array}{l}\text { dark and } \\
\text { light grey }\end{array}$ & oxide mounds & $\begin{array}{l}\text { oxide layering } \\
\text { and flaking }\end{array}$ & & & & 1 & & & \\
\hline $0.04 \mathrm{Sc} 0.18 \mathrm{Th}$ & $\begin{array}{l}\text { interference } \\
\text { colors }\end{array}$ & $\begin{array}{l}\text { brown-black } \\
\text { with grey } \\
\text { patches }\end{array}$ & $\begin{array}{l}\text { dark and } \\
\text { light grey }\end{array}$ & $\begin{array}{l}\text { grey with } \\
\text { white patches }\end{array}$ & & & & & & & \\
\hline $100 \mathrm{zr}$ & $\begin{array}{l}\text { interference } \\
\text { colors }\end{array}$ & black & white flaking & & ! & & 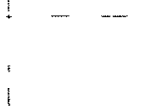 & $L$ & & & \\
\hline
\end{tabular}

"Removed, although appearance justified continuance.

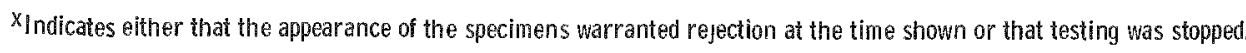


Table IIIA

\begin{tabular}{|c|c|c|c|c|}
\hline \multirow{2}{*}{$\begin{array}{c}\text { Nominal } \\
\text { Composition, } \\
\text { Atomic } \\
\text { Per Cent }\end{array}$} & \multicolumn{4}{|c|}{$\begin{array}{l}\text { Appearance after Test } \\
\text { rs in Steam }\left(540^{\circ} \mathrm{C}, 600 \mathrm{psi}\right)\end{array}$} \\
\hline & 2410 & 3130 & 3886 & 4390 \\
\hline $0.05 \mathrm{Sc} 0.23 \mathrm{Ta}$ & $\begin{array}{l}\text { thick grey } \\
\text { layer, cracks } \\
\text { on surface, } \\
\text { edge attack }\end{array}$ & unchanged & unchanged & $\begin{array}{l}\text { thick grey } \\
\text { layer, } \\
\text { flaking } x\end{array}$ \\
\hline $0.13 \mathrm{Sc} 0.20 \mathrm{~W}$ & $\begin{array}{l}\text { thick grey } \\
\text { layer, } \\
\text { edge attack }\end{array}$ & unchanged & disintegrating $\mathrm{x}$ & \\
\hline $0.07 \mathrm{Sc} 0.22 \mathrm{~W}$ & $\begin{array}{l}\text { thick grey } \\
\text { layer, } \\
\text { edge attack }\end{array}$ & unchanged & unchanged & $\begin{array}{l}\text { thick grey } \\
\text { layer, } \\
\text { flaking } \mathrm{x}\end{array}$ \\
\hline $0.05 \mathrm{Sc} 0.23 \mathrm{~W}$ & $\begin{array}{l}\text { thick grey } \\
\text { layer, } \\
\text { edge attack }\end{array}$ & unchanged & unchanged & $\begin{array}{l}\text { thick grey } \\
\text { layer } \\
\text { flaking } \mathrm{x}\end{array}$ \\
\hline
\end{tabular}

$\mathrm{x}$ Indicates either that the appearance of the specimens warranted rejection at the time shown or that testing was stopped. 
Table IV

RESLITS OF CORROSION TESTING OF YTTRIUM ALLOYS IN THE AS-CAST CONDITION

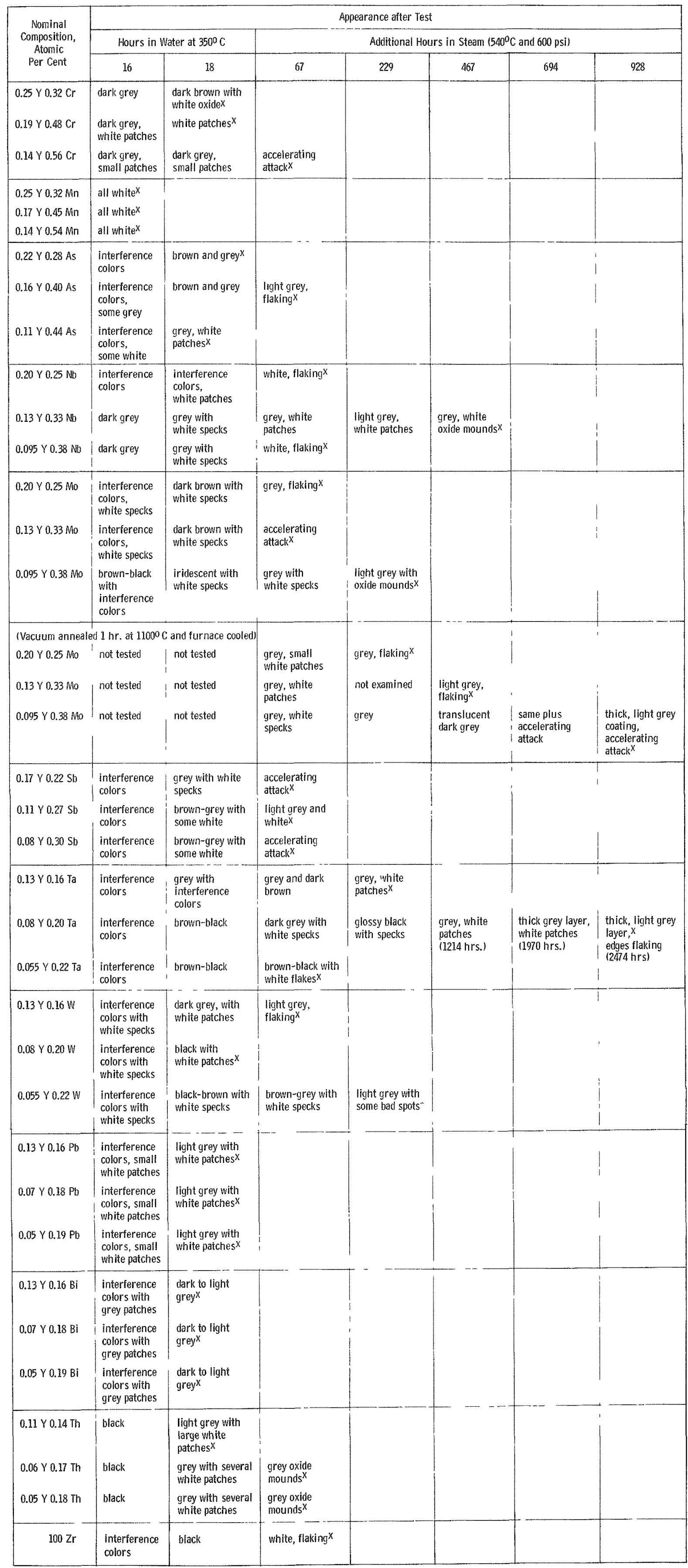

"Removed, although appearance justified continuance.

$\mathrm{x}$ Indicates either that the appearance of the specimens warranted rejection at the time shown or that testing was stopped. 
Table Y

RESULTS OF CORROSION TESTING AFTER VACULM ANNEALING AT $1000^{\circ} \mathrm{C}$ FOR 15 MIN (SEALED IN QUARTZ) AND WATER QUENCHING

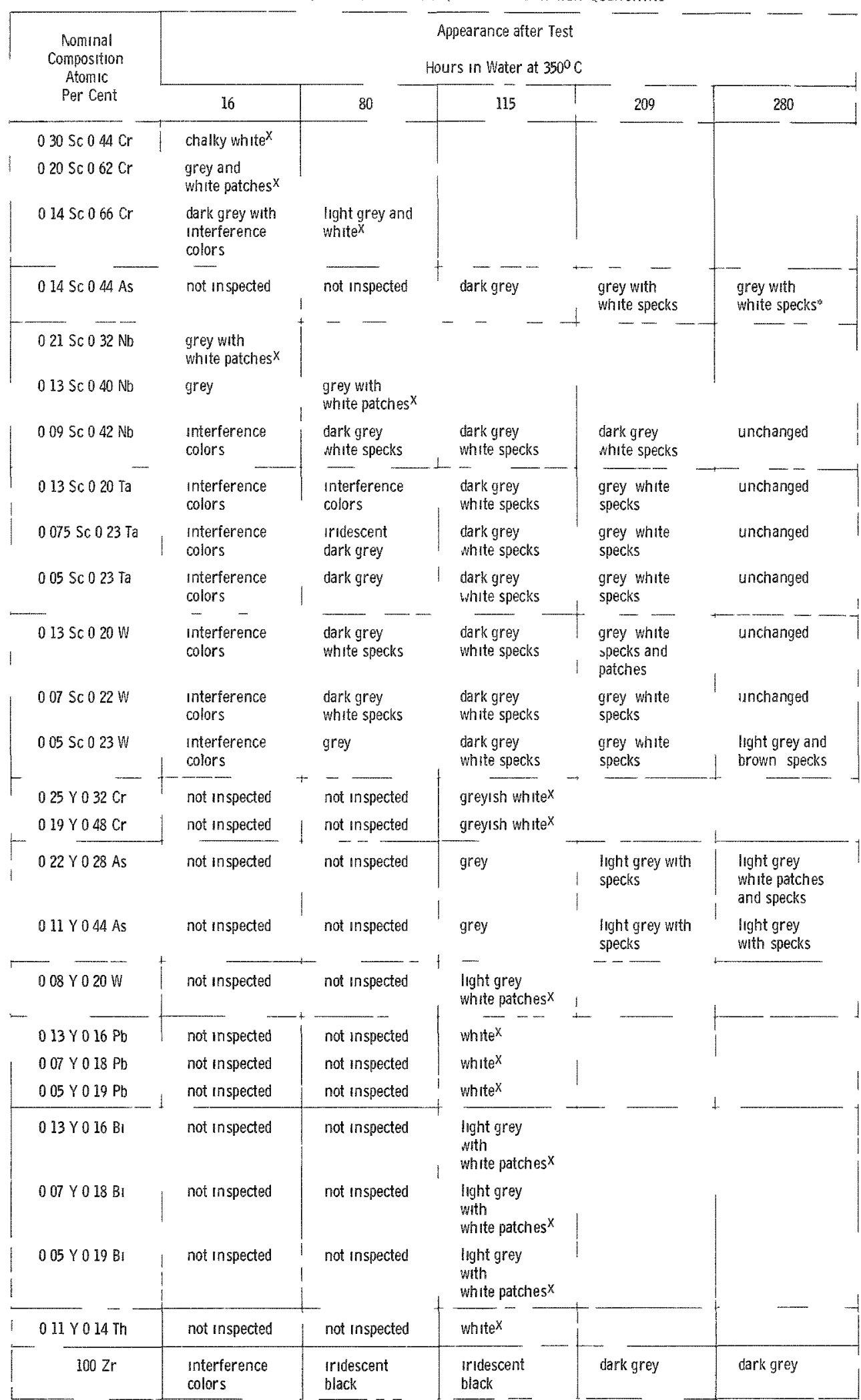

Contunued in $540^{\circ} \mathrm{C} 600$ psi steam Cf Table VI

$x$ Indicates either that the appearance of the specimens warranted rejection at the time shown or that testing was stopped 
Table $\mathrm{D}$

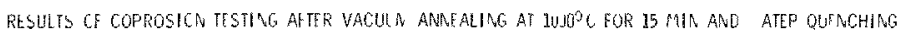

These specimens had an nitral oxide film produced by $200 \mathrm{hr}$ in $350^{\circ} \mathrm{C}$ ater see lable $\mathrm{Wl}$

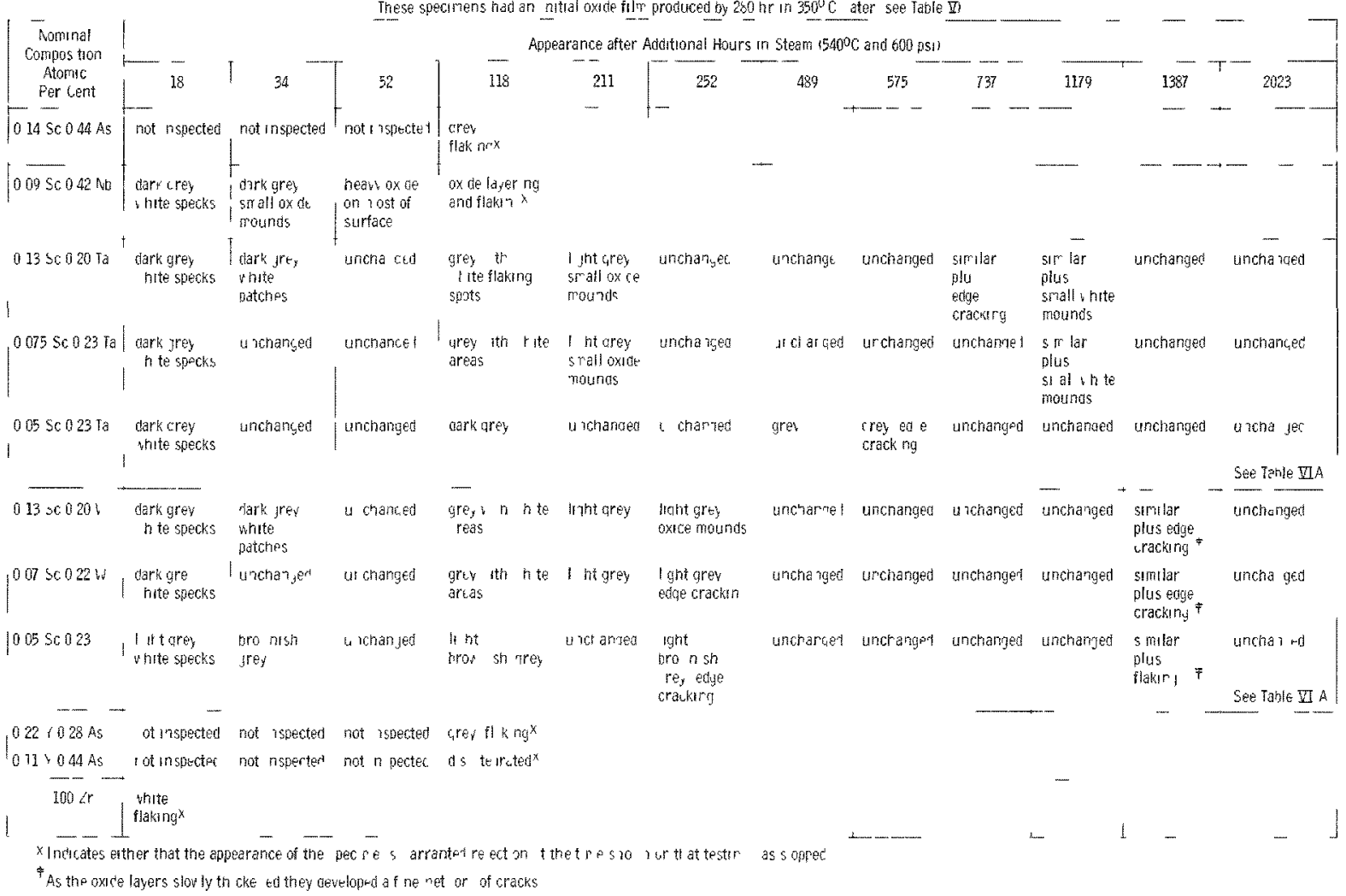

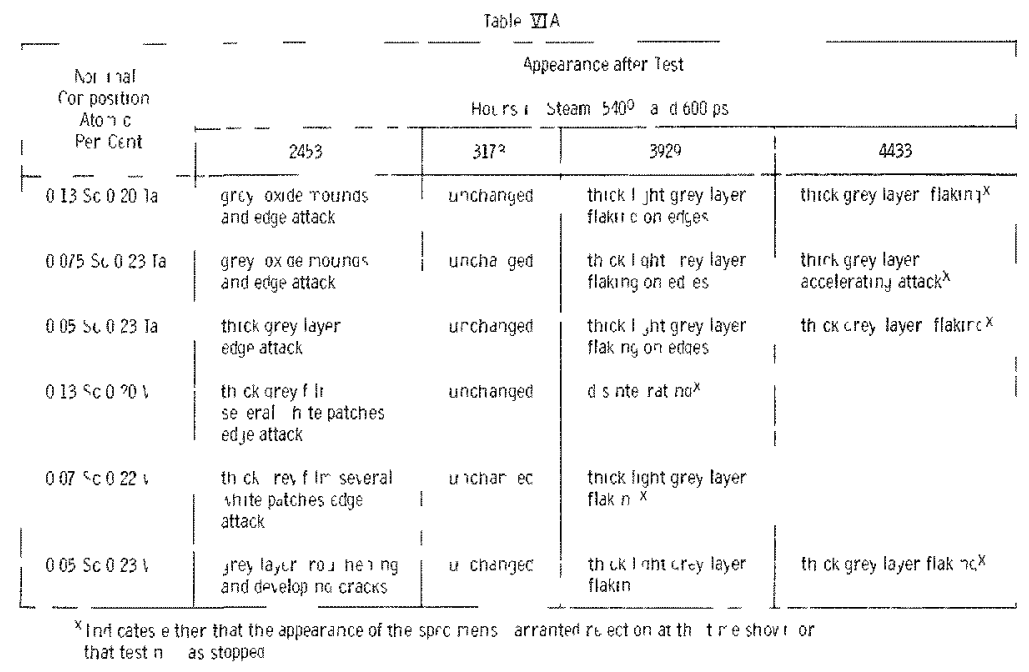


A number of other tests were carried out on alloys containing the combinations $\mathrm{YNb}, \mathrm{YTa}$, and $\mathrm{YbNb}$. These alloys were arc melted, cut in halves, and etched. They were then annealed in evacuated quartz capsules at $900^{\circ} \mathrm{C}$ for $16 \mathrm{hr}$. One-half button was then water quenched, and the other half was furnace cooled. The corrosion data are presented in Table VII. The atomic per cents of $\mathrm{Nb}$ and $\mathrm{Ta}$ are different because the alloys were made up originally on a weight per cent basis. The Nb combinations were far superior to the Ta combinations. Corrosion resistance diminished with increasing $\mathrm{Nb}$ and $\mathrm{Ta}$ content, and heat treatment had only a slight effect. The YNb specimens were weighed periodically, and a linear weight gain with time was indicated. Specific weight gains were not determined.

Table VII

RESULTS OF CORROSION TESTING OF AS-CAST Y, ND AND Y TA ZIRCONIUM ALLOYS

\begin{tabular}{|c|c|c|c|c|c|c|c|c|c|}
\hline \multirow{2}{*}{$\begin{array}{l}\text { Composition, } \\
\text { Atomic } \\
\text { Per Cent }\end{array}$} & \multirow[t]{2}{*}{$\begin{array}{c}\text { Heat } \\
\text { Treatment }\end{array}$} & \multicolumn{8}{|c|}{$\begin{array}{c}\text { Appearance after Test } \\
\text { Hours in Steam }\left(540^{\circ} \mathrm{C}, 600 \mathrm{psi}\right)\end{array}$} \\
\hline & & 64 & 135 & 294 & 503 & 616 & 704 & 1030 & 1190 \\
\hline $0.51 \times 0.98 \mathrm{Nb}$ & $\begin{array}{l}\text { furnace } \\
\text { cooled } \\
\text { quenched }\end{array}$ & $\begin{array}{l}\text { dark grey } \\
\text { iridescent } \\
\text { grey }\end{array}$ & $\begin{array}{l}\text { unchanged } \\
\text { unchanged }\end{array}$ & $\begin{array}{l}\text { some edge } \\
\text { cracking } \\
\text { some edge } \\
\text { cracking }\end{array}$ & $\begin{array}{l}\text { light grey, } \\
\text { some edge } \\
\text { cracking } \\
\text { dark grey, } \\
\text { some edge } \\
\text { cracking }\end{array}$ & $\begin{array}{l}\text { unchanged } \\
\text { unchanged }\end{array}$ & $\begin{array}{l}\text { unchanged } \\
\text { unchanged }\end{array}$ & \multirow{2}{*}{$\begin{array}{l}\text { grey and } \\
\text { white, } \\
\text { many cracks } \\
\text { in the } \\
\text { oxide and } \\
\text { flaking edges }\end{array}$} & \multirow{2}{*}{ unchanged ${ }^{x}$} \\
\hline 0.51 Y $1.96 \mathrm{Nb}$ & $\begin{array}{l}\text { F. C. } \\
\text { Q. }\end{array}$ & $\begin{array}{l}\text { dark grey } \\
\text { iridescent } \\
\text { dark grey }\end{array}$ & $\begin{array}{l}\text { unchanged } \\
\text { unchanged } \\
\text { plus incipient } \\
\text { attack }\end{array}$ & $\begin{array}{l}\text { some edge } \\
\text { cracking } \\
\text { light grey, } \\
\text { some edge } \\
\text { cracking }\end{array}$ & $\begin{array}{l}\text { light grey, } \\
\text { some edge } \\
\text { cracking } \\
\text { light grey, } \\
\text { some edge } \\
\text { cracking }\end{array}$ & $\begin{array}{l}\text { unchanged } \\
\text { unchanged }\end{array}$ & $\begin{array}{l}\text { unchanged } \\
\text { unchanged }\end{array}$ & & \\
\hline 0.51 Y $4.9 \mathrm{Nb}$ & $\begin{array}{l}\text { F. C. } \\
\text { Q. }\end{array}$ & $\begin{array}{l}\text { very thin } \\
\text { white coating } \\
\text { dark grey }\end{array}$ & $\begin{array}{l}\text { unchanged } \\
\text { plus incipient } \\
\text { attack } \\
\text { dark grey } \\
\text { plus incipient } \\
\text { attack }\end{array}$ & $\begin{array}{l}\text { unchanged } \\
\text { unchanged }\end{array}$ & $\begin{array}{l}\text { white, } \\
\text { some edge } \\
\text { cracking } \\
\text { light grey, } \\
\text { some edge } \\
\text { cracking }\end{array}$ & $\begin{array}{l}\text { white, } \\
\text { microscopic } \\
\text { cracks } \\
\text { unchanged }\end{array}$ & $\begin{array}{l}\text { unchanged } \\
\text { unchanged }\end{array}$ & $\begin{array}{l}\text { uniform } \\
\text { white, } \\
\text { flaking }\end{array}$ & $\begin{array}{l}\text { white } \\
\text { flaking } x\end{array}$ \\
\hline 0.51 Y $0.5 \mathrm{Ta}$ & $\begin{array}{c}\text { F. C. } \\
\text { Q. }\end{array}$ & $\begin{array}{l}\text { white, flaking } x \\
\text { black and } \\
\text { white patches }\end{array}$ & $\begin{array}{l}\text { cream color, } \\
\text { accelerating } \\
\text { attack } x\end{array}$ & & & & & & \\
\hline 0.51 Y $1.0 \mathrm{Ta}$ & $\begin{array}{c}\text { F. C. } \\
\text { Q. }\end{array}$ & $\begin{array}{l}\text { white, flaking }{ }^{x} \\
\text { white, flaking }{ }^{x}\end{array}$ & & & & & & & \\
\hline 0.51 Y $2.6 \mathrm{Ta}$ & $\begin{array}{c}\text { F. C. } \\
\text { Q. }\end{array}$ & $\begin{array}{l}\text { white, flaking } x \\
\text { White, flaking } x\end{array}$ & & & & & & & \\
\hline $\mathrm{Zr}$ & $\begin{array}{l}\text { F. C. } \\
\text { Q. }\end{array}$ & $\begin{array}{l}\text { White, flaking } x \\
\text { white, flaking }{ }^{x}\end{array}$ & & & & & & & \\
\hline
\end{tabular}

${ }^{x}$ Indicates either that the appearance of the specimens warranted rejection at the time shown or that testing was stopped.

Ytterbium-niobium combinations were investigated next because of the close crystallochemical similarity of the $\mathrm{Y}^{3+}$ and $\mathrm{Yb}^{3+}$ ions. Alloys were prepared in the same way as the YNb series, and the data are presented in 
Table VIII. The $\mathrm{Yb}$ and $\mathrm{Nb}$ were always in a $1: 1$ atomic ratio. The corrosion results were comparable to those of the $\mathrm{YNb}$ series, confirming the similarity to be expected from such closely related additives. At the end of $687 \mathrm{hr}$, the best specimen appeared to be $0.053 \mathrm{a} / \mathrm{O} \mathrm{Yb}, 0.053 \mathrm{a} / \mathrm{O} \mathrm{Nb}$ as quenched. This alloy was the poorest in the furnace-cooled condition. All four alloys corroded linearly as judged by periodic weighing.

Table VIII

RESULTS OF CORROSION TESTING OF ZIRCONIUM ALLOYS CONTAINING Yb AND Nb

\begin{tabular}{|c|c|c|c|c|c|}
\hline \multirow{2}{*}{$\begin{array}{l}\text { Composition, } \\
\text { Atomic } \\
\text { Per Cent }\end{array}$} & \multirow{2}{*}{$\begin{array}{c}\text { Heat } \\
\text { Treatment }\end{array}$} & \multicolumn{4}{|c|}{$\begin{array}{c}\text { Appearance after Test } \\
\text { Hours in steam }\left(540^{\circ} \mathrm{C} \text { and } 600 \text { psi) }\right.\end{array}$} \\
\hline & & 113 & 201 & 527 & 687 \\
\hline \multirow[t]{2}{*}{$0.026 \mathrm{Yb} 0.026 \mathrm{Nb}$} & F. C. & glossy black & $\begin{array}{l}\text { grey, small } \\
\text { bad spots }\end{array}$ & $\begin{array}{l}\text { light grey, } \\
\text { tiny flakes }\end{array}$ & similar $r^{x}$ \\
\hline & $Q$. & glossy black & $\begin{array}{l}\text { grey, small } \\
\text { bad spots }\end{array}$ & $\begin{array}{l}\text { tan, } \operatorname{tin} y \\
\text { flakes }\end{array}$ & similar $x$ \\
\hline \multirow[t]{2}{*}{$0.053 \mathrm{Yb} 0.053 \mathrm{Nb}$} & $F \cdot C$ & $\begin{array}{l}\text { accelerating } \\
\text { attack }^{x}\end{array}$ & & & \\
\hline & $Q$. & glossy black & $\begin{array}{l}\text { brown and grey, } \\
\text { small bad } \\
\text { spots }\end{array}$ & $\begin{array}{l}\tan \text { and dark } \\
\text { grey }\end{array}$ & $\begin{array}{l}\tan \text { and grey, } \\
\text { small bad } \\
\text { spots }\end{array}$ \\
\hline \multirow[t]{2}{*}{$0.14 \mathrm{Yb} 0.14 \mathrm{Nb}$} & F.C. & glossy black & $\begin{array}{l}\text { grey, small } \\
\text { bad spots }\end{array}$ & light grey & $\begin{array}{l}\text { light grey, } \\
\text { bad spots }\end{array}$ \\
\hline & $Q$. & glossy black & brown and grey & $\begin{array}{l}\tan \text { and dark } \\
\text { grey }\end{array}$ & $\begin{array}{l}\tan \text { and grey, } \\
\text { bad spots } x\end{array}$ \\
\hline \multirow[t]{2}{*}{$0.26 \mathrm{Yb} 0.26 \mathrm{Nb}$} & F. C. & glossy black & $\begin{array}{l}\text { grey, small } \\
\text { bad spots }\end{array}$ & light grey & $\begin{array}{l}\text { light grey, } \\
\text { small flakes }\end{array}$ \\
\hline & $Q$ & glossy black & brown and grey & light grey & $\begin{array}{l}\text { light grey, } \\
\text { small flakes } x\end{array}$ \\
\hline$Z_{r}$ & F. C. & $\begin{array}{l}\text { disintegrating } \mathrm{x} \\
\text { disintegrating } \mathrm{x}\end{array}$ & & & \\
\hline
\end{tabular}

Indicates either that the appearance of the specimens warranted rejection at the time shown or that testing was stopped.

B. Alloys Made with Scandium and Yttrium Metal

Following the above surveys a quantitative comparison was made of selected compositions in a lower range of concentrations. Each component was present in the concentration 0.05 atom per cent. The combinations were YNb, YTa, YbNb, YbTa, ScTh, and ScMo. In contrast with all the previous alloys, in which $\mathrm{Sc}$ and $\mathrm{Y}$ had been added as $\mathrm{Sc}_{2} \mathrm{O}_{3}$ and $\mathrm{Y}_{2} \mathrm{O}_{3}$, these alloys were prepared using arc-melted $\mathrm{Sc}$ and $\mathrm{Y}$. 
Each alloy was prepared as an arc-melted button. Sample discs were analyzed spectroscopically, and the data are given in Table IX. The agreement between nominal and analyzed composition appeared reasonable with the exception of ytterbium.

Table IX

SPECTROSCOPIC ANALYSIS OF TERNARY ALLOYS CONTAINING 0.05 ATOMIC PER CENT A, 0.05 ATOMIC PER CENT B

\begin{tabular}{|c|c|c|c|c|}
\hline \multicolumn{2}{|c|}{$\begin{array}{c}\text { Content of A, } \\
\text { Weight Per Cent }\end{array}$} & \multicolumn{2}{c|}{$\begin{array}{c}\text { Content of B, } \\
\text { Weight Per Cent }\end{array}$} & $\begin{array}{c}\text { Analyzed } \\
\text { Content of Fe, } \\
\text { Weight Per Cent }\end{array}$ \\
\hline Nominal & Analyzed & Nominal & Analyzed & \\
\hline $0.049 \mathrm{Y}$ & $0.04 \mathrm{Y}$ & $0.051 \mathrm{Nb}$ & $0.05 \mathrm{Nb}$ & 0.03 \\
$0.049 \mathrm{Y}$ & $0.04 \mathrm{Y}$ & $0.099 \mathrm{Ta}$ & $0.10 \mathrm{Ta}$ & 0.03 \\
$0.095 \mathrm{Yb}$ & $<0.01 \mathrm{Yb}$ & $0.051 \mathrm{Nb}$ & $0.07 \mathrm{Nb}$ & 0.04 \\
$0.095 \mathrm{Yb}$ & $<0.01 \mathrm{Yb}$ & $0.099 \mathrm{Ta}$ & $0.10 \mathrm{Ta}$ & 0.02 \\
$0.025 \mathrm{Sc}$ & $0.03 \mathrm{Sc}$ & $0.13 \mathrm{Th}$ & $0.3 \mathrm{Th}$ & 0.04 \\
$0.025 \mathrm{Sc}$ & $0.03 \mathrm{Sc}$ & $0.053 \mathrm{Mo}$ & $0.06 \mathrm{Mo}$ & 0.06 \\
$\mathrm{Zr}$ & - & - & - & 0.07 \\
\hline
\end{tabular}

Each button was cold-pressed at $90,000 \mathrm{lb}$ and was stress-relieved by heating in vacuum for one-half hour at $700^{\circ} \mathrm{C}$. After furnace cooling, the buttons were cold-rolled to $\frac{1}{16}$-in. thickness and die-punched to produce $\frac{1}{2}$-in.-diameter discs. Each disc was then stamped, polished, and etched. The discs were divided into three groups. The first group was left as rolled; the second was vacuum annealed at $900^{\circ} \mathrm{C}$ for $16 \mathrm{hr}$ in a quartz capsule and water quenched; the third group was annealed in the same way and furnace cooled. After quenching, the second group required recleaning and etching to remove a thin layer of oxide.

Each composition was first tested in $350^{\circ} \mathrm{C}$ water in the cold-rolled condition. The specimens were examined after 16, 86, and $422 \mathrm{hr}$. All specimens had interference colors after $16 \mathrm{hr}$ and metallic dark grey films after $86 \mathrm{hr}$. After a total of $422 \mathrm{hr}$ all but two alloys and the control had a white, flaking coat. The YTa alloy was black, while the zirconium control and scandium molybdenum alloy were iridescent black.

Another set of specimens representing all three treatments was then exposed to steam at $540^{\circ} \mathrm{C}$ and 600 psi. The results are shown in Table X. As expected, all the specimens which failed in water test were eliminated rapidly in steam. The zirconium control corroded rapidly, whereas the ScMo alloy did not.

\footnotetext{
* The analyses were made by B. H. Meng of the Chemistry Division.
} 
Table $\mathrm{X}$

RESULTS OF CORROSION TESTING OF SELECTED ZIRCONIUM ALLOYS IN STEAM $1540^{\circ} \mathrm{C} 600$ PSU

All components are 005 atomic per cent $\Delta \Delta_{i}$ in rgld ${ }^{2}$ i

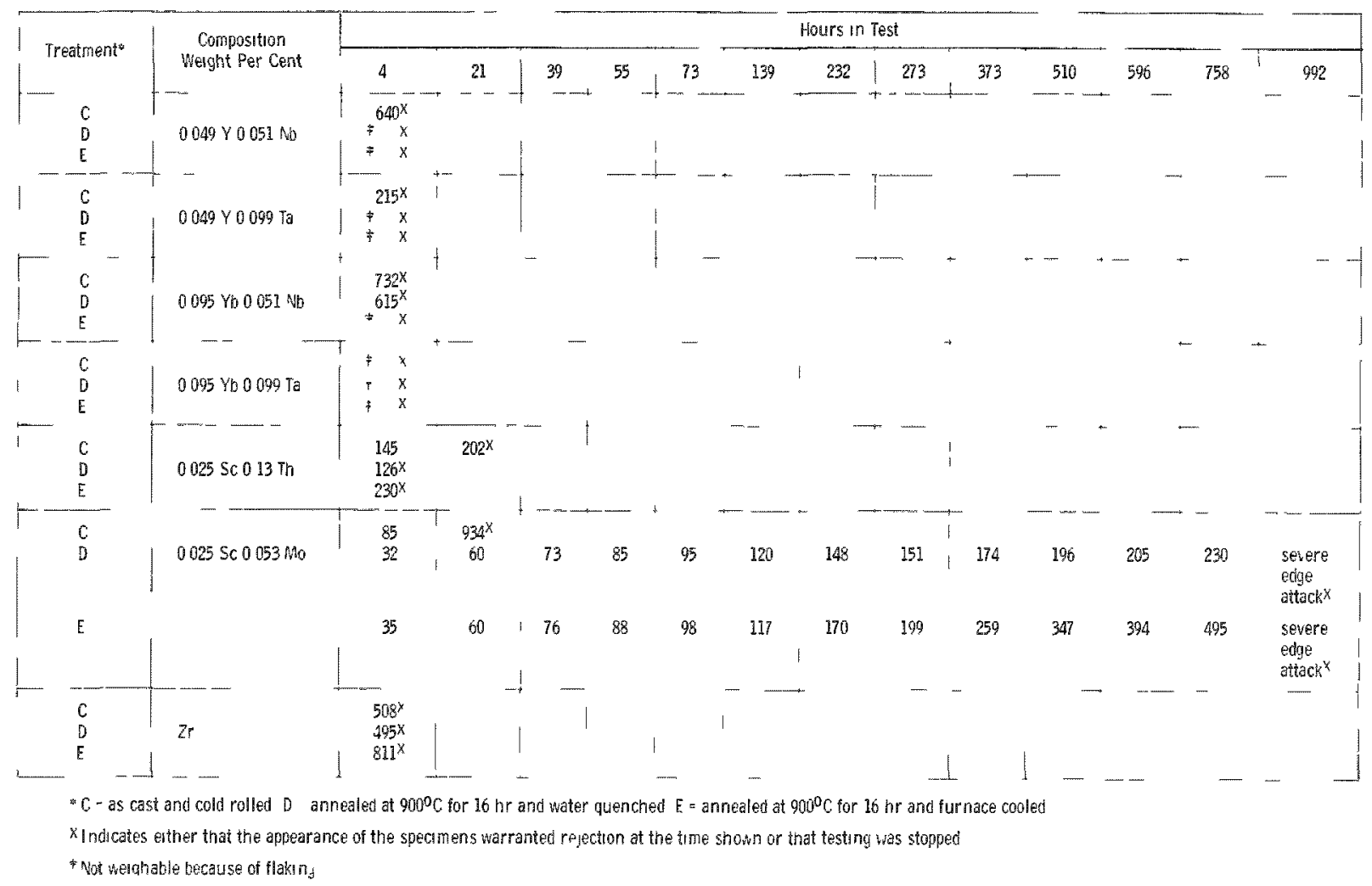

After $758 \mathrm{hr}$, the two remaining ScMo specimens began to suffer accelerated attack on the edges. The appearance of the specimens upon removal is shown in Figure 1, where the specimens from left to right are the cold rolled, quenched, and furnace cooled, respectively. The cold-rolled specimen corroded very rapidly, the annealed and furnace-cooled specimen much less rapidly, and the annealed and quenched specimen had the lowest rate. The welght gains for these specimens are shown in Figure 2 . When the data for the quenched specimen were plotted on log-log coordinates, a straight line was obtained as shown in Figure 3 . The slope was 0.37 , closer to the cube law (slope of 0.33 ) than to the parabolic law (slope of 0.50 ). Such curres are typical of zirconium oxidation in oxygen. (7)

C. Microstructure of a ScMo Alloy

The rapid attack on the specimens of Figure l obviously began at the edge of the $\frac{1}{16}-i n$. -thick disc and moved toward the center. By metallographic polishing parallel to the flat surfaces, it was possible to observe differences in microstructure (hydride preciplation) adjacent to the rapidly corroding area and at the center of the disc. By comparison, any hydride contributed by corrosion of the flat surfaces was negligible. After obtaining micrographs, the specimens were removed from the Lucite mounts and small portions corresponding to the micrographs were cut out by means of shears. 
Figure 1

Specimens of $0.025 \mathrm{w} / 0 \mathrm{Sc}, 0.053 \mathrm{w} / 0 \mathrm{Mo}$ zirconium alloy after exposure to steam at $540^{\circ} \mathrm{C}$ and 600 psi. From left to right: cold rolled (21 hr in steam), annealed and quenched (942 hr in steam), annealed and furnace cooled (492 hr in steam).

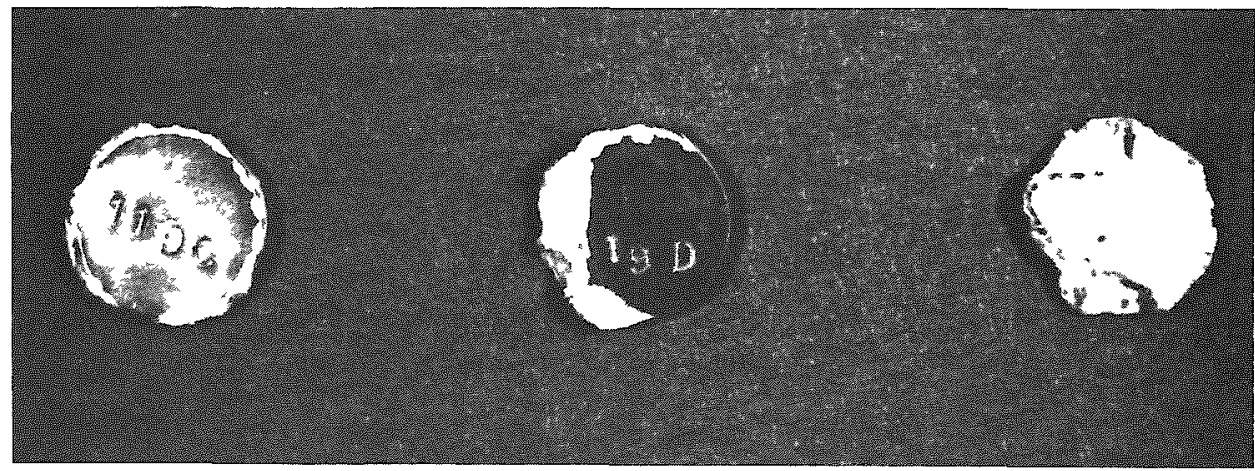

100967

$1 \frac{1}{2} \mathrm{X}$

Figure 2

Weight gans in $\mathrm{mg} / \mathrm{dm}^{2}$ for three specimens of the alloy U. $025 \mathrm{w} / 0 \mathrm{Sc} 0.053 \mathrm{w} / \mathrm{O}$ Mo corroded in steam at $5 \mathrm{w}^{\circ} \mathrm{C}$, and $600 \mathrm{psi} . \mathrm{C}=\mathrm{cold}$-rolled, $\mathrm{D}=$ annealed and

quenched, $E$ = annealed and furnace cooled.

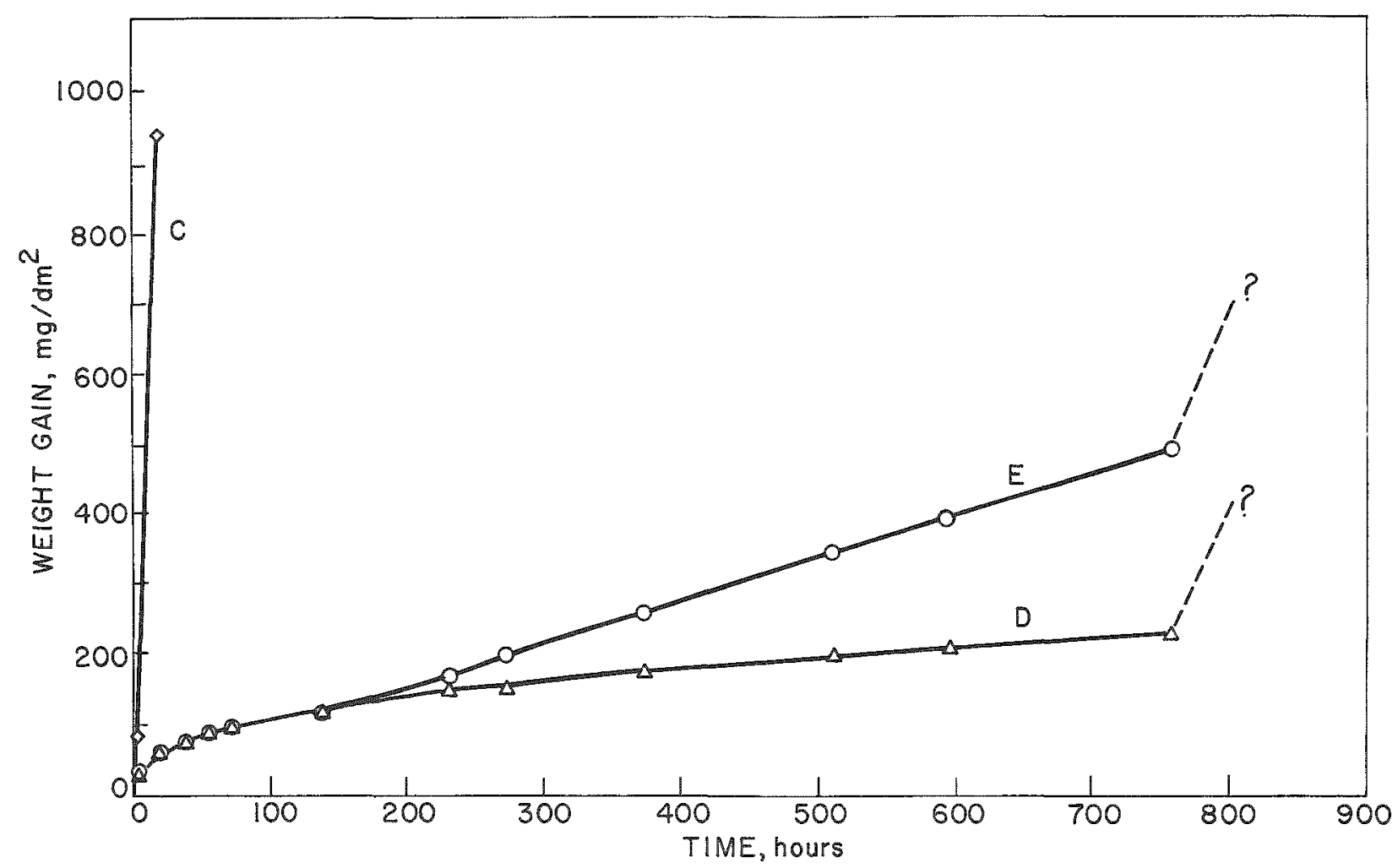


Figure 3

Log-log plor of the data for Specimen B in Figure 2.

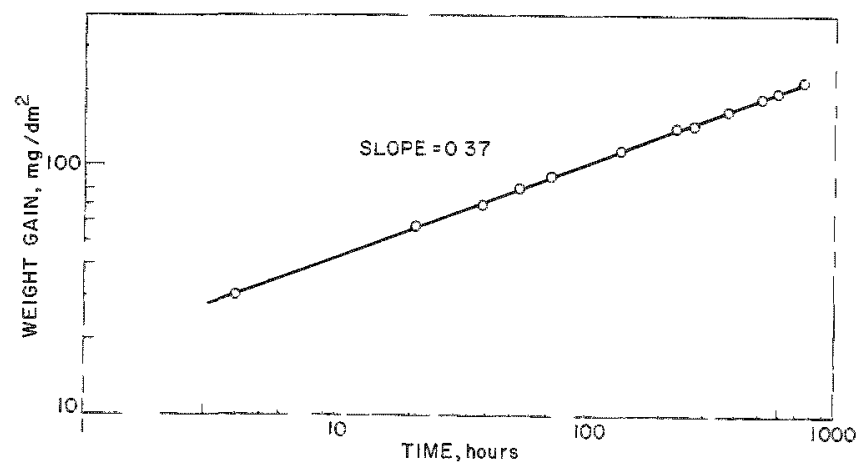

These samples were analyzed for hydrogen by heating to $1200^{\circ} \mathrm{C}$ in vacuum. Micrographs from the cold-rolled specimen (on the left in Figure 1) are given in Figures 4 and 5. More second-phase is evident in Figure 4 than in Figure 5. The annealed and quenched specimen (in the center of Figure 1) provided the micrographs for Figures 6,7 and 8. Figure 6 shows more than $50 \%$ second phase, which was presumed to be zirconium hydride because it diminished toward the center of the specimen as shown in Figure 8.

The hydrogen contents are given in the captions of the figures and summarized in Table XI. It is seen that the alloy before corrosion testing had slightly more hydrogen than the parent zirconium, but the difference was negligible when compared with the amounts after corrosion testing. The rapidly corroding surface of the quenched specimen had a higher hydrogen concentration than the corroding surface of the cold-rolled specimen. It is possible that a higher diffusion rate in the cold-rolledalloy was responsible for this difference.

\section{Examination of Stripped Corrosion Fllms}

The corrosion film was examined from an alloy containing $0.16 \mathrm{w} / \mathrm{O} \mathrm{Sc}$ and $0.34 \mathrm{w} / \mathrm{O} \mathrm{Mo}(0.32 \mathrm{a} / \mathrm{o} \mathrm{Sc}$ and $0.32 \mathrm{a} / \mathrm{O} \mathrm{Mo})$. The alloy was arc melted, machined to a cylinder, vacuum annealed for $16 \mathrm{hr}$ at $900^{\circ} \mathrm{C}$, and water quenched. After cleaning, the specimen was corrosion tested in steam at $540^{\circ} \mathrm{C}$ and 150 psi for $212 \mathrm{hr}$. The specimen had a black oxide film and a weight gain of $427 \mathrm{mg} / \mathrm{dm}^{2}$.

The oxide was removed in the following way. The specimen was molded in a solution of methyl and ethyl methacrylate and most of the metal was remored by grinding. The remainder of the metal was removed anodically in a saturated $\mathrm{ZnCl}_{2}$ solution at room temperature, using approximately $15 \mathrm{~V}$. After removing the products of electrolysis, the transparent corrosion film was examined in an electron microscope. 
Figure 4

Cold-rolled, $0.025 \mathrm{w} / \mathrm{O} \mathrm{Sc}-0.053 \mathrm{w} / 0 \mathrm{Mo}$ alloy showing the interface between metal (light area on left) and oxide (darker area) aftur corrosion in steam. Rapid oxide penetration had just begun in this region. $2420 \mathrm{ppm}$ hydrogen in the zirconium.

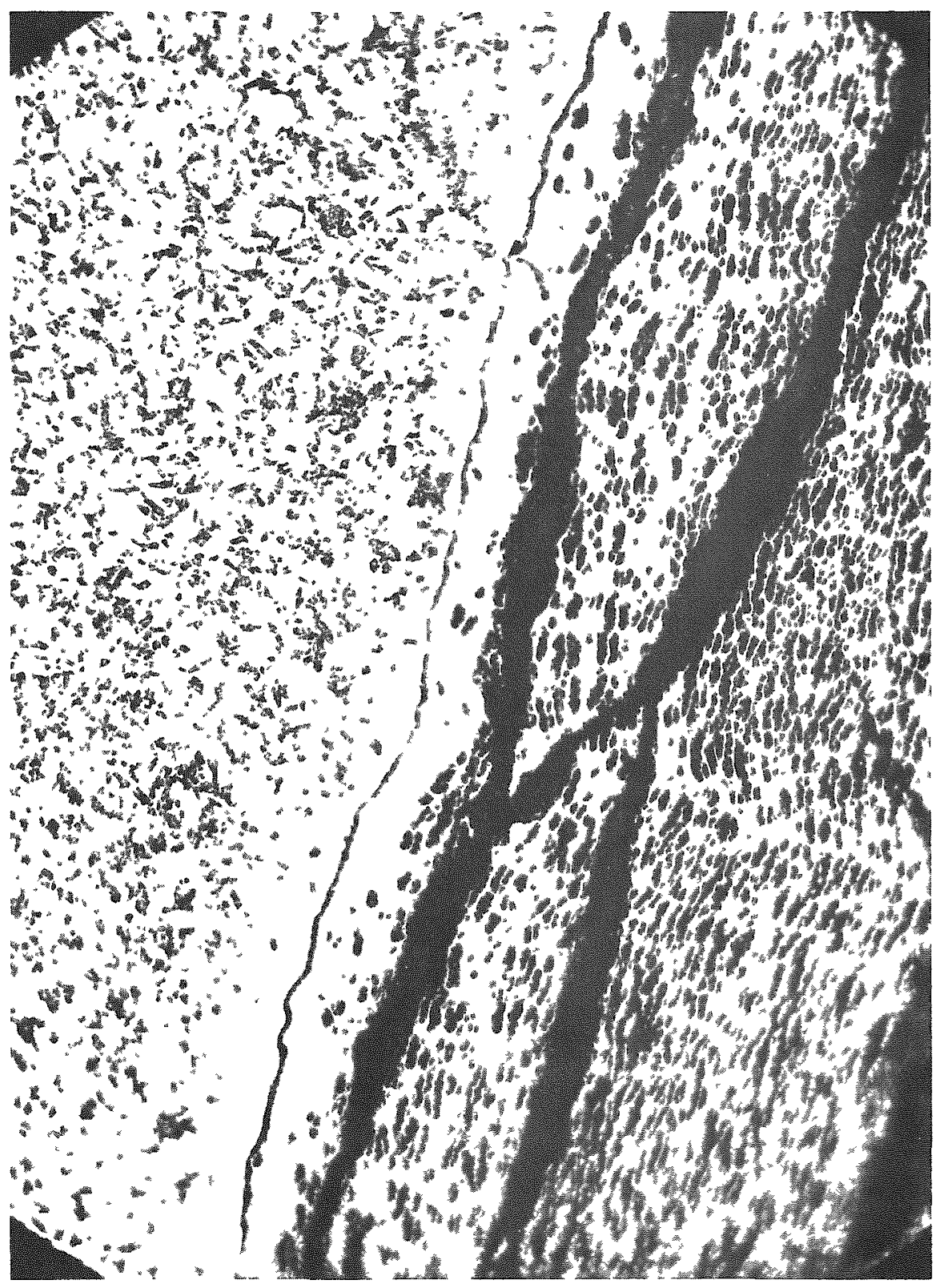


Figure 5

Interior of specimen shown in Figure 4; 1210 ppm hydrogen.

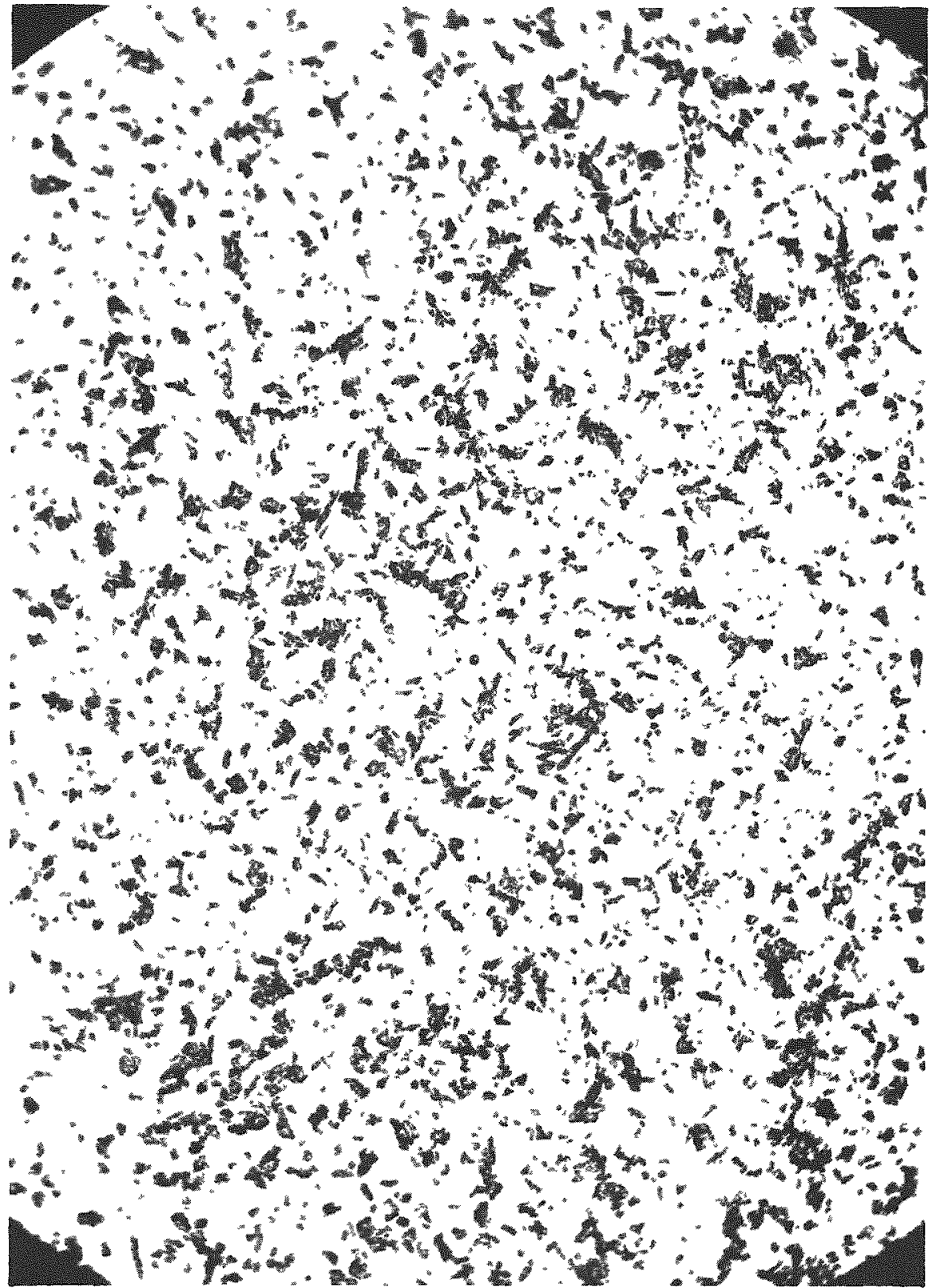


Figure 6

Annealed and quenched $0.025 \mathrm{w} / 0 \mathrm{Sc}-0.053 \mathrm{w} / \mathrm{O}$ Mo alloy showing the interface between oxide (darker area on left) and metal (light area) after corrosion in steam. Rapid oxide penetration was well advanced in this area. $3570 \mathrm{ppm}$ hydrogen in the zirconium.

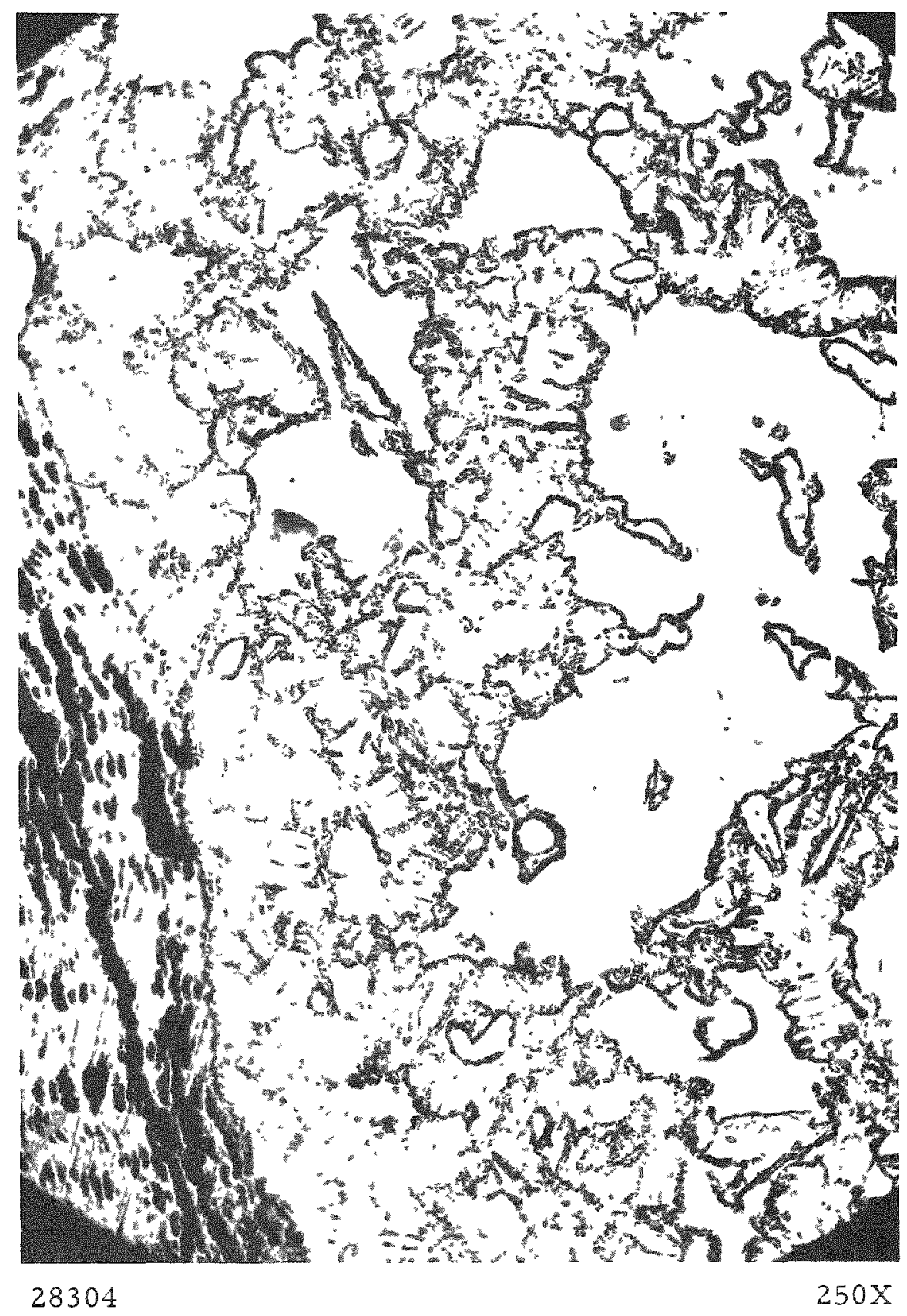


Figure 7

Annealed and quenched $0.025 \mathrm{w} / \mathrm{O} \mathrm{Sc}-0.053 \mathrm{w} / \mathrm{O}$ Mo alloy showng the $1 \mathrm{nter}-$ face berween oxide (grey band on left) and metal (light ared) after corrosion in steam. Rapid oxide penetration had just begun in this area. $1020 \mathrm{ppm}$ by drogen in the Lirconum.

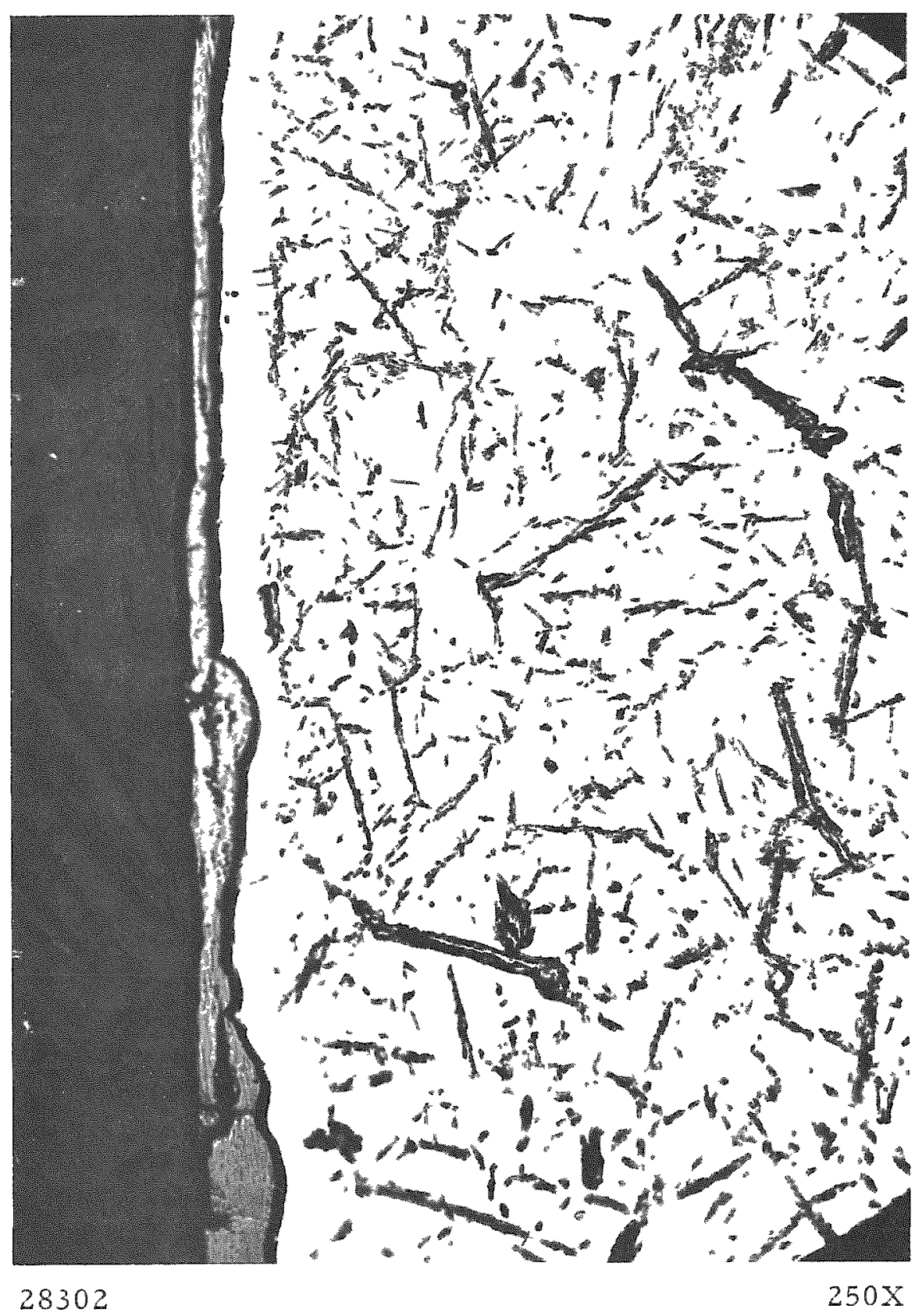


Figure 8

Interior of specimen shown in Figures 6 and 7.

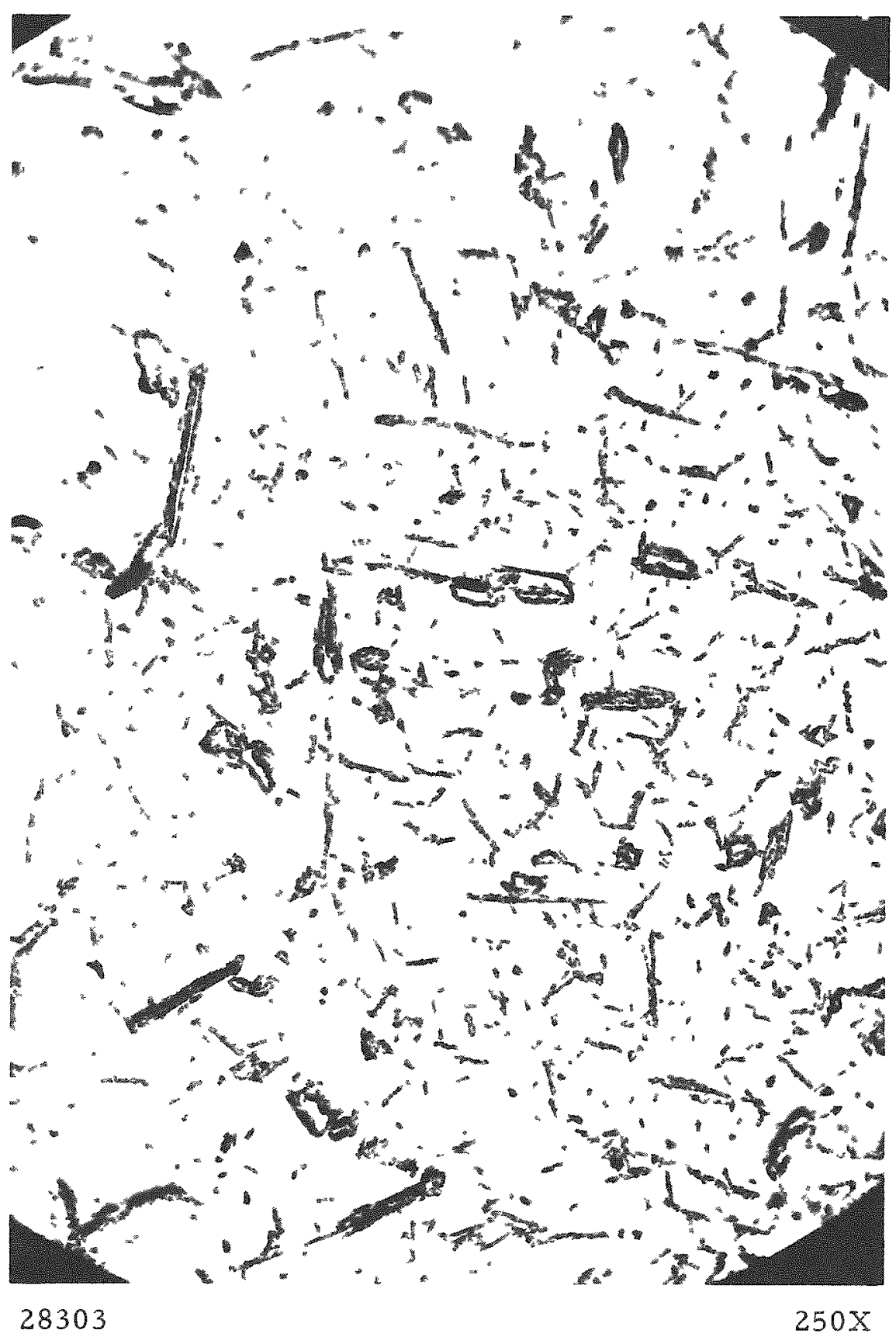


Table XI

HYDROGEN ANALYSES OF ZIRCONIUM SPECIMENS BEFORE AND AFTER CORROSION IN STEAM $\left(540^{\circ} \mathrm{C}\right.$ AND $\left.600 \mathrm{psi}\right)$

\begin{tabular}{|c|c|c|}
\hline $\begin{array}{c}\text { Specimen } \\
\text { Composition }\end{array}$ & History & $\begin{array}{l}\text { Hydrogen Concentration } \\
\text { in Specimen (ppm) }\end{array}$ \\
\hline Zirconium & $\begin{array}{l}\text { Cold rolled but not corrosion } \\
\text { tested (control) }\end{array}$ & $\left.\begin{array}{l}36.1 \\
36.4\end{array}\right\} \quad 36.3$ average \\
\hline $\begin{array}{c}0.025 \mathrm{w} / \mathrm{o} \mathrm{Sc} \\
0.053 \mathrm{w} / \mathrm{o} \mathrm{Mo} \\
\text { alloy }\end{array}$ & $\begin{array}{l}\text { Cold rolled but not corrosion } \\
\text { tested (control) }\end{array}$ & $\left.\begin{array}{l}41.1 \\
58.2\end{array}\right\} 49.7$ average \\
\hline $\begin{array}{c}0.025 \mathrm{w} / \mathrm{O} \mathrm{Sc} \\
0.053 \mathrm{w} / \mathrm{O} \mathrm{Mo} \\
\text { a.lloy }\end{array}$ & $\begin{array}{l}\text { Sample from the metal shown } \\
\text { in Figure } 4 \text {. Cold rolled and } \\
\text { exposed for } 38.5 \mathrm{hr} \text { in steam. }\end{array}$ & 2,420 \\
\hline $\begin{array}{c}0.025 \mathrm{w} / \mathrm{O} \mathrm{Sc} \\
0.053 \mathrm{w} / \mathrm{O} \mathrm{Mo} \\
\text { alloy }\end{array}$ & $\begin{array}{l}\text { Sample from the metal shown } \\
\text { in Figure } 5 \text {. Cold rolled and } \\
\text { exposed for } 38.5 \mathrm{hr} \text { in steam. }\end{array}$ & 1,210 \\
\hline $\begin{array}{c}0.025 \mathrm{w} / \mathrm{O} \mathrm{Sc} \\
0.053 \mathrm{w} / \mathrm{O} \mathrm{Mo} \\
\text { alloy }\end{array}$ & $\begin{array}{l}\text { Sample from the metal shown } \\
\text { in Figure } 6 . \text { Cold rolled, } \\
\text { annealed, and quenched. Ex- } \\
\text { posed for } 992 \text { hr in steam. }\end{array}$ & 3,570 \\
\hline $\begin{array}{c}0.025 \mathrm{w} / \mathrm{O} \mathrm{Sc} \\
0.053 \mathrm{w} / \mathrm{O} \mathrm{Mo} \\
\text { alloy }\end{array}$ & $\begin{array}{l}\text { Sample from the metal shown } \\
\text { in Figure } 7 \text {. Cold rolled, } \\
\text { annealed, and quenched. Ex- } \\
\text { posed for } 992 \text { hr in steam. }\end{array}$ & 1,020 \\
\hline
\end{tabular}

For comparison, dark, iridescent film from corrosion-resistant zirconium crystal bar was examined in the same way. This film resulted from exposure to $315^{\circ} \mathrm{C}$ water for two weeks. The film from zirconium is shown in Figure 9. The dark mottled areas were probably metal. The diffraction pattern showed monoclinic $\mathrm{ZrO}_{2}$, polycrystalline and randomly oriented. Figures 10 and 11 show the film from the ScMo alloy. The clear areas gave a mixed diffraction pattern of $\mathrm{Zr}$ and $\mathrm{ZrO}_{2}$. The $\mathrm{Zr}$ was discretely crystallized without evident preferred orientation, and the $\mathrm{ZrO}_{2}$ was monoclinic, finely crystallized, and randomly oriented. 
Figure 9

Oxide film from zirconium crystal bar exposed to $315^{\circ} \mathrm{C}$ water for two weeks.

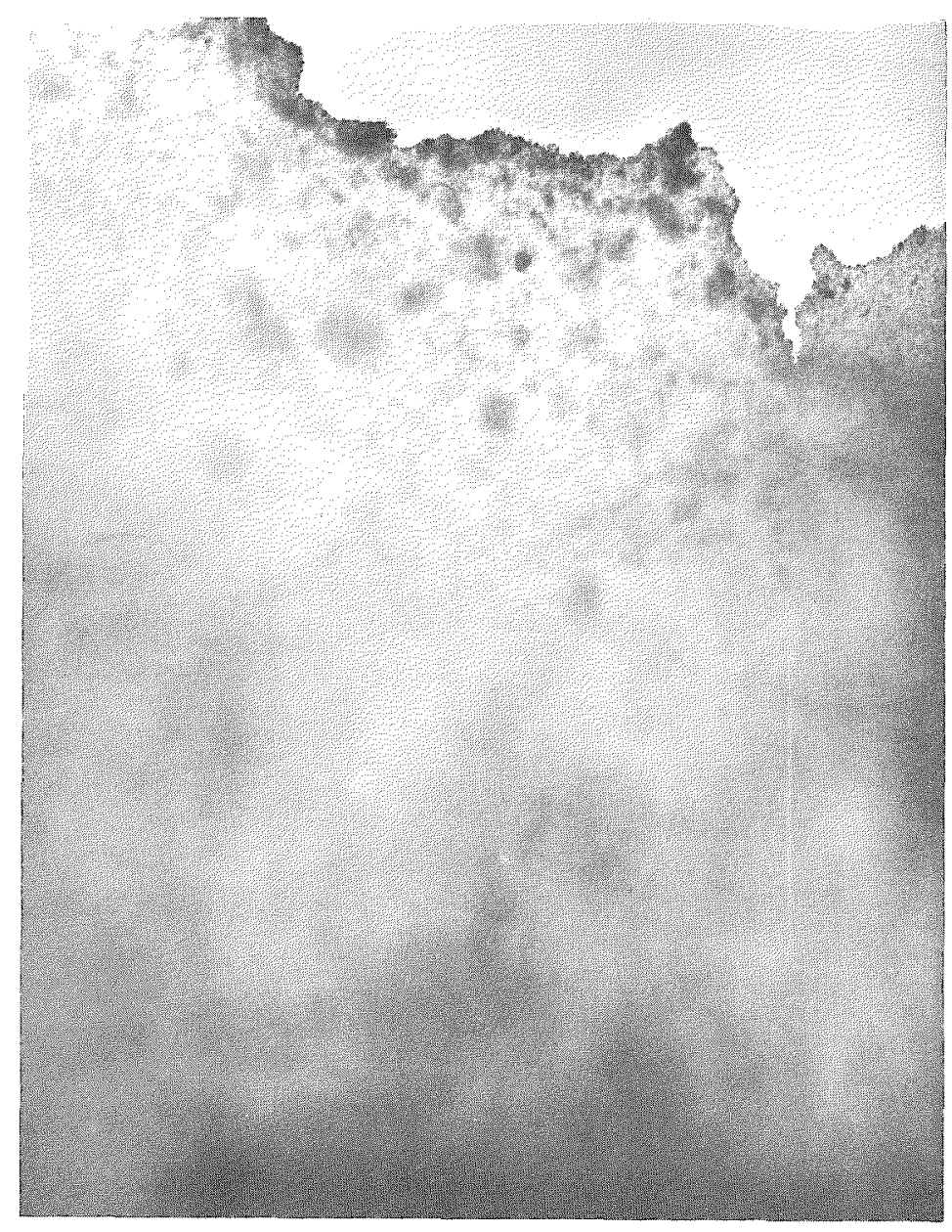

100742
$20,000 x$
Figure 10

Oxide film from an alloy containing $0.15 \mathrm{w} / \mathrm{o} \mathrm{Sc}$ and $0.34 \mathrm{~W} / \mathrm{O} \mathrm{Mo}$, corroded in steam $\left(540^{\circ} \mathrm{C}, 150 \mathrm{psi}\right)$ for $212 \mathrm{hr}$.

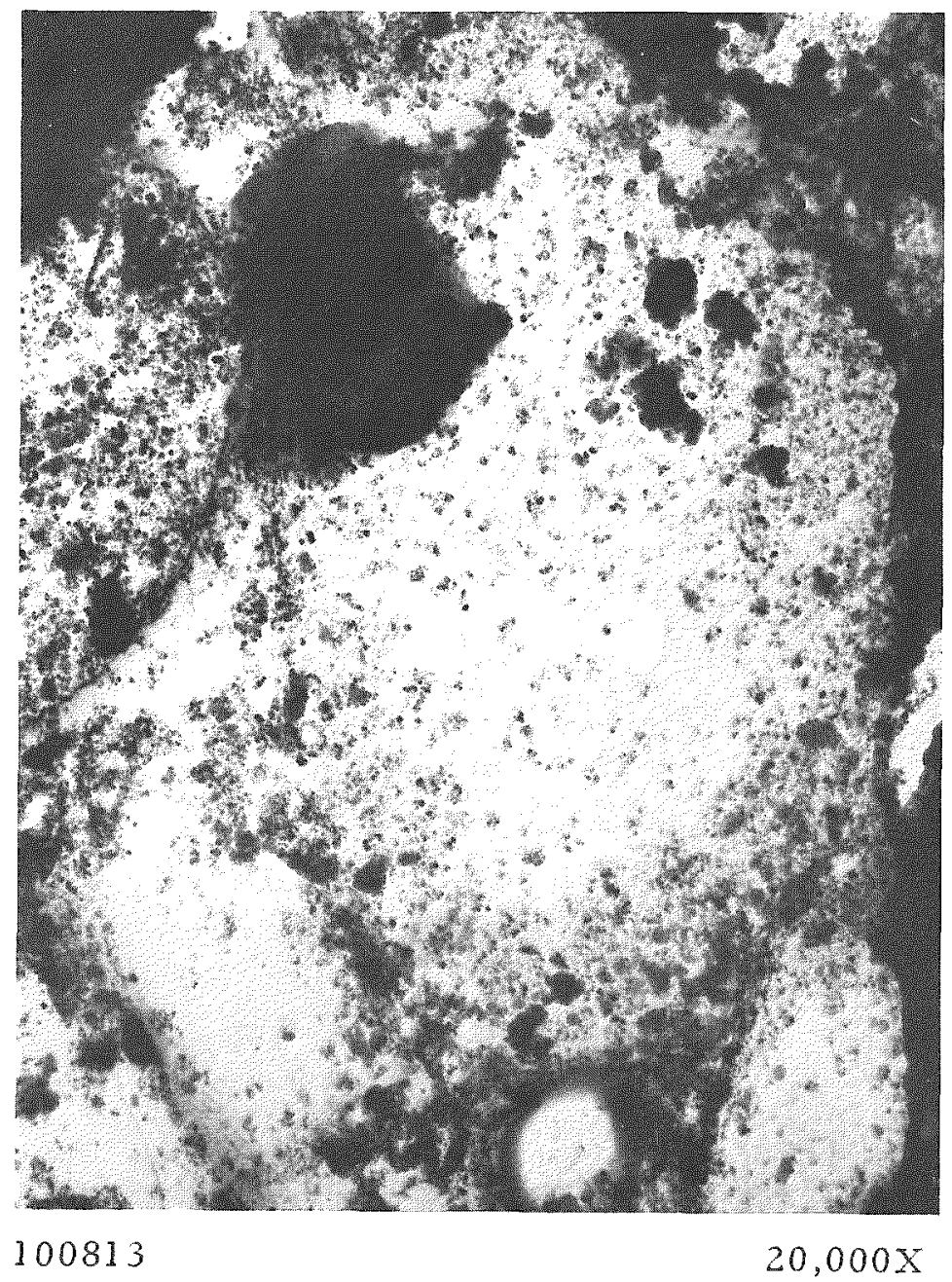


Figure 11

Different area from the same specimen as in Figure $\varphi_{0}$

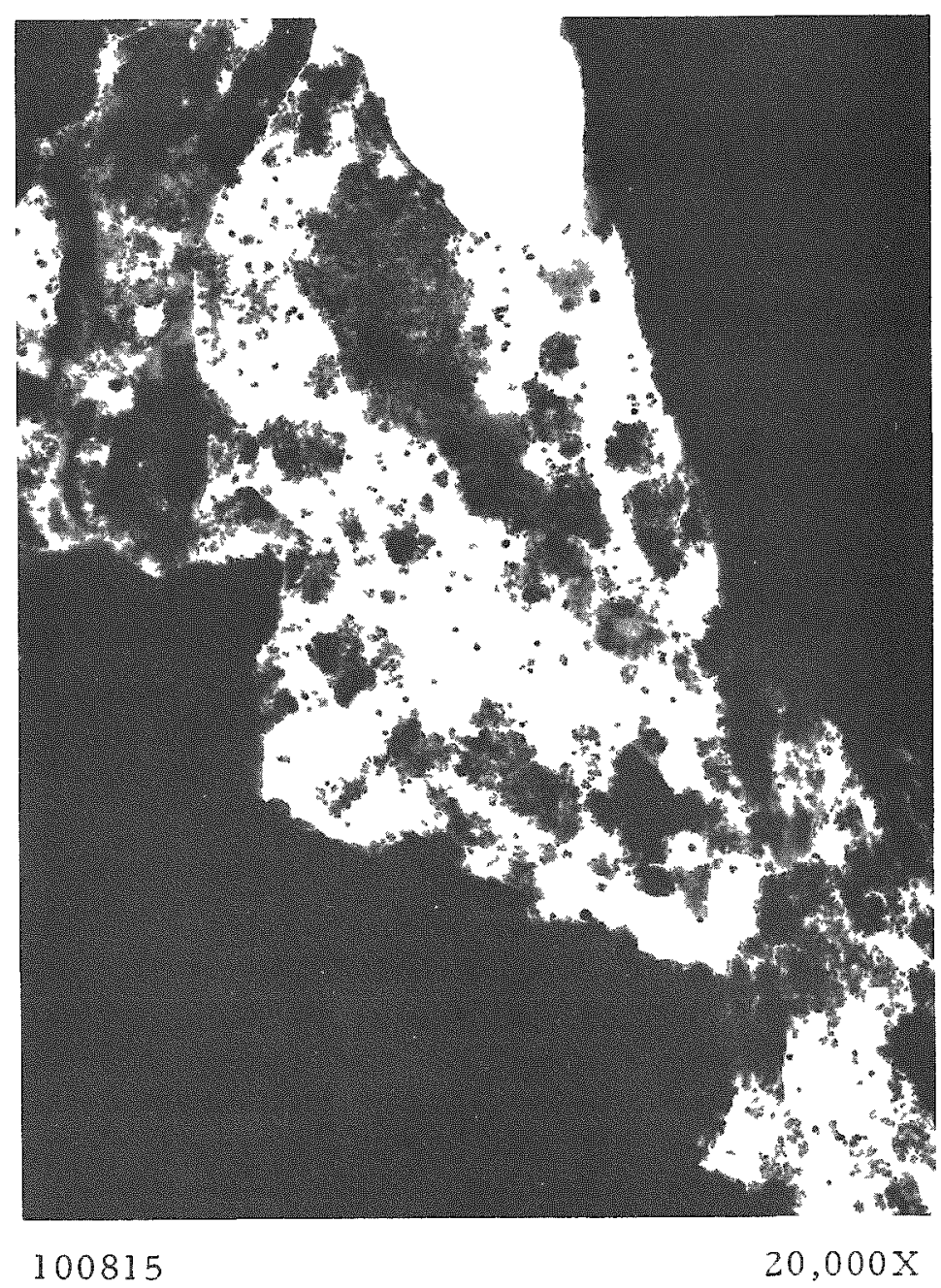




\section{DISCUSSION}

An important aspect of the influence of ternary additions is the solubility of the individual elements in zirconium. The uniformly bad influence of aluminum may be due to the formation of $\mathrm{Zr}_{3} \mathrm{Al}$, which reacts with water and thus can disrupt the $\mathrm{ZrO}_{2}$ film. Because the scandium and yttrium alloys had large differences in corrosion resistance, it is assumed that sufficient solubility existed to permit interaction with the other additive in the oxide film.

In general, scandium was superior to yttrium as an additive. This superiority could be due to any number of factors, and the most profitable investigative approach is believed to lie in examination of the ScMo alloy in detail. Because the oxide on this alloy has no detectable second phase, it is likely that the additives do not appreciably exceed the solid solution range. Because the oxide was monoclinic, it is possible that a compound such as $\mathrm{ScMOO}_{4}$ may exist which favors a monoclinic structure.

Evidence for such a compound is available for combinations of a similar type as seen in the work of Komkov $(8)$ who studied $r$ are earth niobates. The lattice parameters for these mixed oxides are in good correspondence with the parameters for monoclinic $\mathrm{ZrO}_{2}$. An example is $\mathrm{YbNbO}_{4}$, for which a, b, c, and $\beta$ are $5.030 \mathrm{kx}, 10.798 \mathrm{kx}, 5.237 \mathrm{kx}$, and $85^{\circ} 30^{\prime}$, respectively, as compared with $5.21 \mathrm{kx}, 5.26 \mathrm{kx}, 5.37 \mathrm{kx}$, and $80^{\circ} 32^{\prime}$ for $\mathrm{ZrO}_{2}$. The $\mathrm{b}$ value for $\mathrm{ZrO}_{2}$ is doubled when making the comparison. Because $\mathrm{Yb}^{3+}$ and $\mathrm{Y}^{3+}$ have similar ionic radii $(1.00$ and $1.06 \AA$, respectively), a $\mathrm{YNbO}_{4}$ compound may also exist. Consequently, the $\mathrm{YNb}$ and $\mathrm{YbNb}$ combinations were expected to show good corrosion resistance, but this expectation was only partly fulfilled.

It is apparent that properties of the metal and oxide outside the scope of this study may be important variables. In particular, the role of cathodes in preventing film damage must be considered. If the ScMo alloy has a more stable film, then modification of this alloy by the addition of nickel, palladium, or similar elements should be considered for further development.

The interesting behavior of scandium with molybdenum, tantalum, and tungsten suggests a more detailed examination of these elements with reference to their role in the $\mathrm{ZrO}_{2}$ lattice. One of the parameters of interest is the molar volume, which is compared for dioxides in Table XII. These data were obtained from various sources and no attempt was made at critical evaluation.

The available data limited the comparison largely to the rutile structure. The sequence from smaller to larger volumes is probably not very different from what it is in other structures. The volumes for $\mathrm{CeO}_{2}$, $\mathrm{UO}_{2}$, and $\mathrm{ThO}_{2}$ are given because of the close chemical similarity of their cations to $\mathrm{Zr}^{4 t}$. 
Table XII

MOLAR VOLUMES OF $\mathrm{MO}_{2}$ COMPOUNDS

\begin{tabular}{|c|c|c|c|}
\hline $\begin{array}{l}\text { Structure } \\
\text { Type }\end{array}$ & Compound & $\begin{array}{l}\text { Molar } \\
\text { Volume, } \mathrm{cm}^{3}\end{array}$ & $\begin{array}{l}\text { Vol \% Difference } \\
\text { from } \mathrm{ZrO} \mathrm{O}_{2}\end{array}$ \\
\hline $\begin{array}{c}\text { Rutile } \\
\text { tetragonal } \\
\text { C4 }\end{array}$ & $\begin{array}{l}a-\mathrm{MnO}_{2} \\
\varepsilon-\mathrm{CrO}_{2} \\
\mathrm{TiO}_{2} \\
\mathrm{VO}_{2} \\
\mathrm{RuO}_{2} \\
\mathrm{MoO}_{2} \\
\varepsilon-\mathrm{WO}_{2} \\
\mathrm{NbO}_{2} \\
\varepsilon-\mathrm{TaO}_{2} \\
\mathrm{SnO}_{2} \\
\mathrm{HfO}_{2} \\
\mathrm{ZrO}_{2} \\
\mathrm{PbO}_{2} \\
\mathrm{TeO}_{2} \\
\mathrm{SeO}_{2} \\
\mathrm{OsO}_{2}\end{array}$ & $\begin{array}{l}17 \\
17.1 \\
18.9 \\
19.1 \\
19.2 \\
19.7 \\
20.0 \\
20.4 \\
20.4 \\
21.6 \\
21.8 \\
22.0 \\
25.5 \\
26.5 \\
26.6 \\
28.1\end{array}$ & $\begin{array}{r}-22.7 \\
-22.2 \\
-14.1 \\
-13.2 \\
-12.7 \\
-10.5 \\
-9.1 \\
-7.3 \\
-7.3 \\
-1.8 \\
-0.9 \\
0.0 \\
+15.9 \\
+20.2 \\
+20.9 \\
+27.7\end{array}$ \\
\hline $\begin{array}{c}\text { CaF } 2 \\
\text { f.c. } \\
\text { Cubic Cl }\end{array}$ & $\begin{array}{l}\mathrm{CeO}_{2} \\
\mathrm{UO}_{2} \\
\mathrm{ThO}_{2}\end{array}$ & $\begin{array}{l}23.6 \\
24.8 \\
26.4\end{array}$ & $\begin{array}{l}+7.3 \\
+12.7 \\
+20.0\end{array}$ \\
\hline
\end{tabular}

In the rutile series two groups are of particular interest. These are $\mathrm{Mn}, \mathrm{Cr}, \mathrm{Ti}, \mathrm{V}$, and $\mathrm{Mo}, \mathrm{W}, \mathrm{Nb}, \mathrm{Ta}$. The first group did not produce good corrosion resistance in combination with Sc and $Y$, whereas the latter group produced some promising combinations. It is suggested that some deleterious structural changes may be produced in the protective $\mathrm{ZrO}_{2}$ layer when cations of too small a volume are incorporated. Cations of too large a volume may also be harmful, judging by the effect of $\mathrm{PbO}_{2}$. However, data are insufficient on this point. 
The favorable combinations involved $\mathrm{MoO}_{2}, \mathrm{WO}_{2}, \mathrm{NbO}_{2}$, and $\mathrm{TaO}_{2}$ with slightly smaller molar volumes than $\mathrm{ZrO}_{2}$. Therefore, adjustment to the $\mathrm{ZrO}_{2}$ lattice will not be difficult and some compensation for compressive stresses in the film may be possible. If these ions are found in the penta- or hexavalent state when dissolved in $\mathrm{ZrO}_{2}$, then a further decrease in molar volume of an " $\mathrm{MO}_{2}$ " unit is to be expected.

If scandium and molybdenum ions are both present in the $\mathrm{ZrO}_{2}$ lattice, it is probable that the lattice will be expanded in the vicinity of scandium and contracted in the vicinity of molybdenum. This is evident because of the different coulombic attraction by cations of different valence and the fact that $\mathrm{MO}^{6+}$ is much smaller than $\mathrm{Sc}^{3+}$. Presumably a favorable volume change can be produced by a certain ratio of lower to higher valence additive and this may be the case for scandium and molybdenum.

Another factor which will determine the effect of a dissolved cation is the cation field strength relative to $\mathrm{Zr}^{4+}$. This factor is defined as $\mathrm{Z} / \mathrm{a}^{2}$, where $Z$ is the valence and $a$ is the distance from the cation to the nearest oxygen. Dietzel and Tober $(9)$ compiled a table of such values in reviewing phase diagrams of $\mathrm{ZrO}_{2}$ and other oxides. The list is presented in Table XIII, and it is obvious that the oxides which form compounds with $\mathrm{ZrO}_{2}$ have cation field strengths which differ appreciably from that of zirconium. The oxides between $\mathrm{MgO}$ and $\mathrm{TiO}_{2}$ correspond to field strengths which are within \pm 0.3 unit of the two values for $\mathrm{ZrO}_{2}$. The two values come from the monoclinic and cubic structures, which have different coordinations.

It is apparent that scandium is closer in cation field strength than yttrium but that both are within the solid solution range. The oxides of molybdenum, tantalum, and tungsten did not appear in the original table.

All the elements which are known to be favorable to the corrosion resistance of zirconium fall within the \pm 0.3 range. This criterion is obviously limited, however, because many of these oxides, such as $\mathrm{ThO}_{2}$ and $\mathrm{Al}_{2} \mathrm{O}_{3}$, are harmful. Certain of these harmful oxides are known to promote the cubic form of $\mathrm{ZrO}_{2}$, and this property may be a factor in lowering the corrosion resistance of zirconium. Conversion of part of the protective layer to cubic $\mathrm{ZrO}_{2}$ would result in cracks, thereby rendering most of the oxide barrier ineffectual. Additives such as molybdenum may compensate for a tendency of scandium and yttrium to favor the cubic form of $\mathrm{ZrO}_{2}$. In the presence of two different ions, such as $\mathrm{Sc}^{3+}$ and $\mathrm{Mo}^{6+}$, the less symmetrical monoclinic structure may be favored as opposed to the cubic structure, which is favored by symmetrical coulombic bonding. 
Table XIII

RELATIVE CATION FIELD STRENGTHS AND
COMPOUND FORMATION WITH $\mathrm{ZrO}_{2}$

(Dietzel and Tober)

\begin{tabular}{|c|c|c|c|c|}
\hline \multirow{2}{*}{ Oxide } & \multirow{2}{*}{$2 / a^{2}$} & \multirow{2}{*}{ Coordination } & \multicolumn{2}{|c|}{ Compounds } \\
\hline & & & Formula & Melting Point \\
\hline $\mathrm{Na}_{2} \mathrm{O}$ & 0.17 & VIII & $\mathrm{Na}_{2} \mathrm{ZrO}_{3}$ & incongr.? \\
\hline $\mathrm{Li}_{2} \mathrm{O}$ & 0.23 & VI & $\mathrm{Li}_{2} \mathrm{ZrO}_{3}$ & $?$ \\
\hline $\mathrm{BaO}$ & 0.24 & VIII & $\mathrm{BaZrO}_{3}$ & congr. \\
\hline $\mathrm{SrO}$ & 0.27 & VIII & $\mathrm{SrZrO}$ & congr. \\
\hline $\mathrm{CaO}$ & 0.33 & VIII & $\mathrm{CaZrO}_{3}$ & congr. \\
\hline $\mathrm{PbO}$ & 0.34 & VI & $\mathrm{PbZrO}_{3}$ & $?$ \\
\hline $\mathrm{CdO}$ & 0.44 & VI & $\mathrm{CdZrO}_{3}$ & $?$ \\
\hline $\mathrm{La}_{2} \mathrm{O}_{3}$ & 0.44 & VIII & $?$ & \\
\hline $\mathrm{MgO}$ & 0.45 & VI & none & \\
\hline $\mathrm{MnO}$ & 0.48 & VI & $"$ & \\
\hline $\mathrm{Y}_{2} \mathrm{O}_{3}$ & 0.49 & VIII & $" 1$ & \\
\hline $\mathrm{FeO}$ & 0.52 & VI & $"$ & \\
\hline $\mathrm{CoO}$ & 0.53 & VI & $"$ & \\
\hline $\mathrm{NiO}$ & 0.55 & $\mathrm{VI}$ & $"$ & \\
\hline $\mathrm{ZnO}$ & 0.59 & IV & $"$ & \\
\hline $\mathrm{ThO}_{2}$ & 0.64 & VIII & $"$ & \\
\hline $\mathrm{Sc}_{2} \mathrm{O}_{3}$ & 0.65 & VI & $" 1$ & \\
\hline $\mathrm{ZrO} \mathrm{O}_{2}$ & 0.78 & VIII $0.95 \mathrm{VI}$ & - & \\
\hline $\mathrm{CeO}_{2}$ & 0.83 & VIII & none & \\
\hline $\mathrm{Al}_{2} \mathrm{O}_{3}$ & 0.84 & VI & 11 & \\
\hline $\mathrm{BeO}$ & 0.87 & IV & $"$ & \\
\hline $\mathrm{Cr}_{2} \mathrm{O}_{3}$ & 0.95 & VI & 11 & \\
\hline $\mathrm{TiO}_{2}$ & 1.25 & VI & none & \\
\hline $\mathrm{B}_{2} \mathrm{O}_{3}$ & 1.45 & IV & $?$ & \\
\hline $\mathrm{SiO}_{2}$ & 1.57 & IV & $\mathrm{ZrSiO} 4$ & incongr. \\
\hline $\mathrm{V}_{2} \mathrm{O}_{5}$ & 1.85 & IV & $\mathrm{ZrV}_{2} \mathrm{O}_{7}$ & incongr. \\
\hline $\mathrm{P}_{2} \mathrm{O}_{5}$ & 2.08 & IV & $\mathrm{Zr} \mathrm{P}_{2} \mathrm{O}_{7}$ & incongr. \\
\hline $\mathrm{As}_{2} \mathrm{O}_{5}$ & 2.15 & IV & $\begin{array}{l}\mathrm{ZrO}\left(\mathrm{As}_{2} \mathrm{O}_{3}\right)_{2} \\
(\mathrm{ZrO})_{2} \mathrm{As}_{2} \mathrm{O}_{7} \\
(\mathrm{ZrO})_{3}\left(\mathrm{AsO}_{4}\right)_{2}\end{array}$ & $\begin{array}{l}\text { incongr. } \\
\text { incongr. } \\
\text { incongr. }\end{array}$ \\
\hline
\end{tabular}

On the basis of the above considerations, the structural requisite of a protective $\mathrm{ZrO}_{2}$ film is believed to be the maintenance of a uniform barrier of monoclinic oxide. Any factor that will cause this barrier to break up will increase the corrosion rate. Some possibilities in this 
regard are the formation of cracks due to the metastable formation of tetragonal or cubic $\mathrm{ZrO}_{2}$, the hydrolyzing of foreign oxide inclusions, e.g., $\mathrm{Al}_{2} \mathrm{O}_{3}$, or the presence of zirconates or other zirconium compounds.

\section{ACKNOW LEDGEMENTS}

The authors wish to thank J.E. Draley and A. E. Dwight for helpful discussions and suggestions as well as $R$. K. Hart who also made the electron-microscope examinations of stripped oxides. 


\section{REFERENCES}

1. B. Lustman and F. Kerze, Jr., The Metallurgy of Zixconium, McGrawHill, New York (1955), page 631.

2. J. E.Draley and W. E. Ruther, Some Unusual Effects of Hydrogen in Corrosion Reactions, J. Electrochem. Soc., 104, 329-333 (1957).

3. Jin-ichi Takamura and Yasuo Sasaki, Study on the Oxidation Resistance of Zirconium, Technical Reports of the Engineering Research Institute, Kyoto University, 9, No. 6, Report No. 58 (March 1959).

4. B. Lustman and F. Kerze, Jr., The Metallurgy of Zirconium, McGraw Hill, New York (1955), page 637.

5. K. Hauffe, Reaktionen in und an festen Stoffen, Springer Verlag, Berlin (1955).

6. J.R. Johnson, Development of a Cubic Oxide Protective Film on Zir conium, ORNL-2029(Feb 13, 1956).

7. H. A. Porte, J. G. Schnizlein, R. C. Vogel, and D. F. Fischer, Oxidation of Zirconium and Zirconium Alloys. J. Electrochem. Soc. 107, $506-515(1960)$.

8. A. I. Komkov, X-ray Investigation of Artificial Rare-earth Compounds of the RNbO, Type, Doklady Akad. Nauk, S.S.S.R. 126, 853-4 (1959)

9 A. Dietzel and H. Tober. Uber Zirkonoxyd und Zweistoffsysteme mat Zirkonoxyd, Berichte der Deutschen Keramischen Gesselschait 30 , $71-82(1953)$. 